\title{
Non-oxygen induced retinitis proliferans and retinal detachment in full-term infants
}

\author{
F. H. STEFANI ${ }^{1}$ AND HEIDI EHALT ${ }^{2}$ \\ Department of Pathology, Institute of Ophthalmology, London
}

During the past 19 years the case histories relating to seventeen enucleated eyes have been filed in the Department of Pathology under the term "non-oxygen induced retinitis proliferans in full-term infants". The histological appearances resembled those of retrolental fibroplasia although the babies concerned did not appear to have been given supplemental oxygen and were full-term infants judging by their birthweight and the period of gestation.

In the following retrospective study, the histological findings and the infants' subsequent development are reviewed in an attempt to arrive at an accurate classification, and the differential diagnosis is discussed.

\section{Material}

Two of the seventeen infants were later diagnosed as cases of Norrie's disease because there were further male siblings with leucocoria and further details of the family history became available. This study is therefore based on fifteen patients, in ten of whom both eyes showed pathological changes (Group A) while in five only the enucleated eye was affected (Group B).

Questionnaires sent to the ophthalmologist who did the enucleation, and to other doctors who had had charge of the child, elicited replies in nine cases, six bilateral and three unilateral.

\section{Findings}

\section{Glinical data at the tíme of enugleation}

Table I contains all relevant information about the two groups of patients: sex, age when ocular abnormality was first noticed, clinical appearance of each eye, age at enucleation, pregnancy, mother's health, family history.

(a) Clinical findings in enucleated eye

MIGROPHTHALMOS

This was reported in three of Group A (cases I, 7, I0) and in four of Group B (Cases I I,

1. Supported by a grant of the Deutsche Forschungsgemeinschaft at the Institute of Ophthalmology, Department of Pathology London, England, while on leave of absence from the University Hospital of Ophthalmology, Munich, Germany.

2. Supported by a grant of the Bundesministerium $\mathrm{f}$. Wissenschaft und Forschung, Austria, at the Institute of Ophthalmology,

Department of Pathology, London, England, while on leave of absence from the University Hospital of Ophthalmology, Graz,
Austria. 
Table I Clinical particulars of fifteen cases

\begin{tabular}{|c|c|c|c|c|c|c|c|c|c|}
\hline \multirow{2}{*}{$\begin{array}{l}\text { Case } \\
\text { no. }\end{array}$} & \multirow{2}{*}{$\begin{array}{l}\text { Reference } \\
\text { no. }\end{array}$} & \multirow[t]{2}{*}{ Sex } & \multirow{2}{*}{$\begin{array}{l}\text { Age at } \\
\text { first } \\
\text { sign }\end{array}$} & \multirow{2}{*}{$\begin{array}{l}\text { First } \\
\text { sign }\end{array}$} & \multirow{2}{*}{$\begin{array}{l}\text { Side } \\
\text { of } \\
\text { enucle } \\
\text { ation }\end{array}$} & \multirow{2}{*}{$\begin{array}{l}\text { Age at } \\
\text { enucle- } \\
\text { ation } \\
\text { (mths) }\end{array}$} & \multicolumn{2}{|l|}{ Clinical appearance } & \multirow{2}{*}{$\begin{array}{l}\text { Additional information } \\
\text { at time of enucleation }\end{array}$} \\
\hline & & & & & & & Enucleated eye & Fellow eye & \\
\hline \multirow[t]{3}{*}{1} & $13206 / 54$ & $\begin{array}{l}\text { Male } \\
\text { (Figs 21, } \\
22,23)\end{array}$ & $\begin{array}{l}\text { Not } \\
\text { known }\end{array}$ & $\begin{array}{l}\text { Leuco- } \\
\text { coria }\end{array}$ & $\mathbf{R}$ & $2 \frac{1}{2}$ & $\begin{array}{l}\text { Microphthalmos } \\
\text { Small pupil filled } \\
\text { with } \\
\text { dense grey mass } \\
\text { No anterior chamber }\end{array}$ & $\begin{array}{l}\text { Fundus filled with } \\
\text { grey mass } \\
\text { Vague red reflex } \\
\text { except upper nasal } \\
\text { quadrant }\end{array}$ & $\begin{array}{l}\text { Fif th child of } 37 \text {-year- } \\
\text { old mother } \\
\text { Toxoplasma dye test } \\
\text { of mother positive } \\
\text { Toxoplasma dye test } \\
\text { of child negative }\end{array}$ \\
\hline & $29565 / 60$ & $\begin{array}{l}\text { Male } \\
\text { (Fig. 24) }\end{array}$ & Birth & $\begin{array}{l}\text { Leuco- } \\
\text { coria }\end{array}$ & $\mathbf{R}$ & 3 & $\begin{array}{l}\text { Opacities in vitreous } \\
\text { Small pupil } \\
\text { No anterior chamber }\end{array}$ & $\begin{array}{l}\text { Opacities in vitreous } \\
\text { Shallow anterior } \\
\text { chamber }\end{array}$ & $\begin{array}{l}\text { Mother had influenza } \\
\text { pregnancy }\end{array}$ \\
\hline & $20684 / 61$ & $\begin{array}{l}\text { Male } \\
\text { (Fig. 3) }\end{array}$ & $\begin{array}{l}\text { Not } \\
\text { known }\end{array}$ & $\begin{array}{l}\text { Not } \\
\text { known }\end{array}$ & $\mathrm{L}$ & 24 & $\begin{array}{l}\text { Retinal detachment } \\
\text { with retinal vessels } \\
\text { on surface }\end{array}$ & $\begin{array}{l}\text { Localized detachment } \\
\text { on temporal side } \\
\text { Scattered patches of } \\
\text { haemorrhages and } \\
\text { exudates }\end{array}$ & $\begin{array}{l}\text { Positive toxoplasma } \\
\text { dye test of mother } \\
\text { Doubtful positive } \\
\text { toxoplasma dye test of } \\
\text { child }\end{array}$ \\
\hline 4 & $9084 / 61$ & $\begin{array}{l}\text { Female } \\
\text { (Figs 13, } \\
\text { 14) }\end{array}$ & $4 \mathrm{mths}$ & $\begin{array}{l}\text { Leuco- } \\
\text { coria }\end{array}$ & $\mathbf{L}$ & 10 & $\begin{array}{l}\text { Retrolental mass } \\
\text { with new blood } \\
\text { vessels }\end{array}$ & $\begin{array}{l}\text { Greyish-white sheet } \\
\text { in retina }\end{array}$ & Jamaican \\
\hline 5 & $7546 / 62$ & $\begin{array}{l}\text { Male } \\
\text { (Figs 19, } \\
20 \text { ) }\end{array}$ & $\begin{array}{l}\text { Not } \\
\text { known }\end{array}$ & $\begin{array}{l}\text { Leuco- } \\
\text { coria }\end{array}$ & $\mathbf{L}$ & 7 & $\begin{array}{l}\text { Retrolental mass } \\
\text { Shallow anterior } \\
\text { chamber }\end{array}$ & Retrolental mass & $\begin{array}{l}\text { Mental retardation } \\
\text { Epileptic convulsions }\end{array}$ \\
\hline 6 & $23406 / 62$ & $\begin{array}{l}\text { Male } \\
\text { (Fig. 18) }\end{array}$ & Birth & $\begin{array}{l}\text { Leuco- } \\
\text { coria }\end{array}$ & $\mathbf{R}$ & 6 & $\begin{array}{l}\text { Buphthalmos } \\
\text { High tension } \\
\text { Retrolental grey mass } \\
\text { New vessels on } \\
\text { surface } \\
\text { Dentate processes } \\
\text { Ectropion }\end{array}$ & $\begin{array}{l}\text { Slightly smaller } \\
\text { Normal tension } \\
\text { Retrolental mass } \\
\text { No new vessels or } \\
\text { dentate processes }\end{array}$ & Small testicles \\
\hline 7 & $18627 / 63$ & $\begin{array}{l}\text { Female } \\
\text { (Figs 15, } \\
16,17 \text { ) }\end{array}$ & Birth & $\begin{array}{l}\text { Leuco- } \\
\text { coria }\end{array}$ & $\mathbf{R}$ & $4 \frac{1}{2}$ & $\begin{array}{l}\text { Microphthalmos } \\
\text { Retrolental mass } \\
\text { Shallow anterior } \\
\text { chamber }\end{array}$ & Retinal folds & $\begin{array}{l}\text { Mother took tablets } \\
\text { containing antimony } \\
\text { at beginning of preg- } \\
\text { nancy for } 3 \text { to } 4 \text { mths }\end{array}$ \\
\hline 8 & $5933 / 64$ & $\begin{array}{l}\text { Male } \\
\text { (Fig. 4) }\end{array}$ & $5 \frac{1}{2}$ mths & $\begin{array}{l}\text { Leuco- } \\
\text { coria }\end{array}$ & $?$ & 6 & $\begin{array}{l}\text { Retrolental mass } \\
\text { Shallow anterior } \\
\text { chamber }\end{array}$ & Retrolental mass & $\begin{array}{l}\text { Birth weight } 2 \cdot 23 \mathrm{~kg} \text {. } \\
\text { Gestation } 40 \text { wks and } \\
3 \text { days } \\
\text { First } 6 \text { wks in incu- } \\
\text { bator but no supple- } \\
\text { mentary oxygen } \\
\text { Syndactyly of two } \\
\text { fingers of left hand } \\
\text { Convulsions }\end{array}$ \\
\hline 9 & $13109 / 65$ & $\begin{array}{l}\text { Male } \\
\text { (Fig. 5) }\end{array}$ & $\begin{array}{l}\text { Not } \\
\text { known }\end{array}$ & $\begin{array}{l}\text { Unable } \\
\text { to fix } \\
\text { with } \\
\text { either } \\
\text { eye }\end{array}$ & $\mathbf{L}$ & 11 & $\begin{array}{l}\text { Disorganized blood } \\
\text { in anterior chamber }\end{array}$ & $\begin{array}{l}\text { Pale area on nasal } \\
\text { fundus with } \\
\text { haemorrhage }\end{array}$ & \\
\hline 10 & $62292 / 66$ & $\begin{array}{l}\text { Male } \\
\text { (Figs 6, } \\
\text { 7) }\end{array}$ & $\begin{array}{l}\text { Not } \\
\text { known }\end{array}$ & $\begin{array}{l}\text { Leuco- } \\
\text { coria }\end{array}$ & L & 2 & $\begin{array}{l}\text { Microphthalmos } \\
\text { Greyish mass in } \\
\text { upper nasal fundus } \\
\text { Shallow anterior } \\
\text { chamber }\end{array}$ & $\begin{array}{l}\text { Greyish mass in } \\
\text { upper nasal fundus }\end{array}$ & $\begin{array}{l}\text { Caesarian delivery } \\
\text { because of breech } \\
\text { presentation and dis- } \\
\text { tress of foetus } \\
\text { Longer fingers noticed } \\
\text { at age } 3 \text { wks }\end{array}$ \\
\hline 11 & $19659 / 58$ & $\begin{array}{l}\text { Male } \\
\text { (Figs 25, } \\
26,27 \text { ) }\end{array}$ & Birth & $\begin{array}{l}\text { Micro- } \\
\text { phthal- } \\
\text { mos }\end{array}$ & $\mathbf{L}$ & 5 & $\begin{array}{l}\text { Microphthalmos } \\
\text { Retrolental greyish } \\
\text { mass } \\
\text { Shallow anterior } \\
\text { chamber } \\
\text { High tension }\end{array}$ & Normal & 3 wks postmature \\
\hline 12 & $17078 / 60$ & $\begin{array}{l}\text { Female } \\
\text { (Figs 1, } \\
\text { 2) }\end{array}$ & Birth & $\begin{array}{l}\text { Micro- } \\
\text { phthal- } \\
\text { mos }\end{array}$ & $\mathbf{R}$ & 3 & $\begin{array}{l}\text { Microphthalmos } \\
\text { Mass in nasal part of } \\
\text { vitreous }\end{array}$ & Normal & \\
\hline 13 & $27249 / 61$ & $\begin{array}{l}\text { Female } \\
\text { (Figs } 8 \text {, } \\
9 \text { ) }\end{array}$ & $1 \mathrm{mth}$ & $\begin{array}{l}\text { Micro- } \\
\text { phthal- } \\
\text { mos } \\
\text { Strabis- } \\
\text { mus }\end{array}$ & L & 8 & $\begin{array}{l}\text { Microphthalmos } \\
\text { Retrolental mass } \\
\text { Shallow anterior } \\
\text { chamber }\end{array}$ & Normal & \\
\hline 14 & $59455 / 66$ & $\begin{array}{l}\text { Male } \\
\text { (Figs 10, } \\
\text { 11) }\end{array}$ & $\begin{array}{l}\text { Not } \\
\text { known }\end{array}$ & $\begin{array}{l}\text { Strabis- } \\
\text { mus }\end{array}$ & $\mathbf{L}$ & 8 & $\begin{array}{l}\text { Microphthalmos } \\
\text { Retrolental mass } \\
\text { Shallow anterior } \\
\text { chamber }\end{array}$ & Normal & $\begin{array}{l}\text { Mother had previous } \\
\text { miscarriage } \\
\text { Forceps delivery for } \\
\text { delay in second stage }\end{array}$ \\
\hline 15 & $31003 / 69$ & $\begin{array}{l}\text { Male } \\
\text { (Fig. 12) }\end{array}$ & $\begin{array}{l}\text { Not } \\
\text { known }\end{array}$ & $\begin{array}{l}\text { Leuco- } \\
\text { coria }\end{array}$ & $\mathbf{R}$ & 3 & $\begin{array}{l}\text { Retrolental mass } \\
\text { Shallow anterior } \\
\text { chamber }\end{array}$ & Normal & \\
\hline
\end{tabular}


I 2, I3, I4). One case in Group A (6) showed buphthalmos in the enucleated eye and microphthalmos in the fellow eye.

RETROLENTAL MASS

This was reported in six of Group A (Cases 4, 5, 6, 7, 8, I0) and four of Group B (Cases I I, I $3,14,15)$.

VITREOUS OPAGITIES AND MASSES

Opacities were noted in one of Group A (Case 2) and a greyish mass in the nasal fundus in one of Group A (Case 10) and one of Group B (Case 12).

RETINAL DETAGHMENT

This was seen in one of Group A (Case 3).

ANTERIOR GHAMBER

Disorganized blood was reported in the anterior chamber in one of Group A (Case 9).

The anterior chamber was shallow in four of Group A (Cases 5, 7, 8, 10) and absent in two (Cases I, 2). It was shallow in four of Group B 'Cases I I, I3, I4, I5).

INTRAOGULAR PRESSURE

High tension was reported in one of Group A (Case 6) and one of Group B (Case I I). NEOVASGULARIZATION

This was reported in two of Group A (Cases 4,6 ).

DENTATE PROGESSES

Seen in one of Group A (Case 6).

PUPIL

This was small in two of Group A (Cases I, 2). In Case $I$ the pupil was filled with dense grey matter.

GATARACT

This was not observed clinically in any case, but was found in most of the histological studies.

(b) Clinical findings in fellow eye

All the fellow eyes in Group B were found to be normal when examined under general anaesthesia, and the three which were re-examined were still normal at follow-up.

In Group A the fellow eyes all showed pathological changes. These are set out in Table I. Of the six which were re-examined at follow-up, four were the same (Cases 4, 5, 6, 10), one (Case I) had progressed to show a retrolental mass and cataract, and one (Case 9) showed leucocoria (Table III, p. 494).

(c) General abnormalities

GROUP A Case 5 Mental retardation and convulsions.

Case 8 Syndactyly and convulsions

Case 6 Small testicles

Case ro Long fingers 
GROUP B None

(d) Maternal history

GROUP A Case I

Case 2 Mother had influenza in 8th week.

Case 3 Mother's toxoplasma dye test positive (infant's doubtful).

Case $7 \quad$ Mother took antimony tablets.

Case $8 \quad$ Gestation 40 weeks and 3 days. Birth weight $2 \cdot 23 \mathrm{~kg}$. First 6 weeks in incubator, but without supplemental oxygen.

Case Io Breech presentation, foetal distress, Caesarean delivery.

GROUP B Case II 3 weeks post-mature.

Case I4 Previous miscarriage; forceps delivery in second stage.

\section{Histologigal Data}

The findings in the fifteen enucleated eyes are set out in Table II. There were no cases of neoplasm, retinoschisis, or coloboma. All the globes showed total retinal detachment, all (except Case 12) albuminous subretinal exudate, and all an angioblastic process with neovascularization on the inner surface of the retina. All but two showed subretinal ingrowth of retinal vessels, and all but one glomerular endothelial proliferation. Other prominent features were intraocular haemorrhage, glial proliferation in the retina, posterior and anterior synechiae, and cataractous changes in the lens.

Table II Histopathological findings 
I I . Fol low-up (See Table III)

The nine replies received (six in Group A and three in Group B) contributed fresh information about the families as well as bringing our knowledge of the children's progress up to date.

GROuP A Case I The child was deaf but otherwise normal. His four siblings were normal.

Case 5 The child now showed stunted growth as well as mental retardation. Chromosomal abnormality was discovered. His younger brother and his mother's sister's son were similarly retarded, but their chromosomes were normal.

Case 9 The child's mother and younger brother both had an unusual facies with hypertelorism and anisocoria. The patient had had a head injury at the time of enucleation and the ophthalmologist suggested that he might have been a "battered" baby.

GROUP B No further abnormalities were brought to light.

Table III Follow-up of six bilateral and three unilateral cases

\begin{tabular}{|c|c|c|c|c|c|c|}
\hline $\begin{array}{l}\text { Case } \\
\text { no. }\end{array}$ & $\begin{array}{l}\text { Remaining } \\
\text { eye }\end{array}$ & $\begin{array}{l}\text { Physical and mental } \\
\text { development }\end{array}$ & $\begin{array}{l}\text { Chromosomal } \\
\text { abnormalities }\end{array}$ & Siblings & $\begin{array}{l}\text { Other } \\
\text { abnormalities } \\
\text { in family }\end{array}$ & $\begin{array}{l}\text { Other } \\
\text { observations }\end{array}$ \\
\hline 1 & $\begin{array}{l}\text { Cataract } \\
\text { Retrolental } \\
\text { mass }\end{array}$ & $\begin{array}{l}\text { Deaf, otherwise } \\
\text { normal }\end{array}$ & None & $\begin{array}{l}4 \\
\text { One brother lost eye } \\
\text { after injury, otherwise all } \\
\text { developed normally }\end{array}$ & None & \\
\hline 4 & Unchanged & Normal & Not known & Not known & None & \\
\hline 5 & Unchanged & $\begin{array}{l}\text { Stunted growth } \\
\text { Mental retardation } \\
\text { Convulsions }\end{array}$ & $\begin{array}{l}46 X Y \text { with } \\
\text { prominent satellites } \\
\text { on one group D } \\
\text { chromosome }\end{array}$ & $\begin{array}{l}\text { One brother } 2 \text { yrs } \\
\text { younger, similar conditions; } \\
\text { normal chromosomes }\end{array}$ & $\begin{array}{l}\text { Son of maternal } \\
\text { aunt, similar } \\
\text { conditions }\end{array}$ & \\
\hline 6 & Unchanged & $\begin{array}{l}\text { Normal when last } \\
\text { seen at } 6 \mathrm{mths}\end{array}$ & Not examined & Not known & Not known & \\
\hline 9 & Leucocoria & $\begin{array}{l}\text { Normal } \\
\text { Brother also normal }\end{array}$ & None & $\begin{array}{l}\text { Unusual facial appearance } \\
\text { with hypertelorism and } \\
\text { anisocoria }\end{array}$ & $\begin{array}{l}\text { Mother's face } \\
\text { similar to } \\
\text { brother's }\end{array}$ & $\begin{array}{l}\text { Head injury } \\
\text { at time of } \\
\text { enucleation }\end{array}$ \\
\hline 10 & Unchanged & Normal & None & Not known & Not known & \\
\hline 12 & Normal & Normal & Not known & $\begin{array}{l}\text { One healthy younger } \\
\text { sister }\end{array}$ & None & \\
\hline 13 & Normal & Normal & None & Younger brother healthy & None & \\
\hline 14 & Normal & Normal at $22 \mathrm{mths}$ & Not suspected & Not known & None & \\
\hline
\end{tabular}

*In Cases 2, 3, 7, 8, 11, and 15, no follow-up was available

\section{Discussion}

In reviewing the clinical and histological findings in these cases, together with the follow-up information, a number of entities must be considered in the differential diagnosis. Recalling briefly their salient features, we will discuss them separately in relation to our cases, under the following headings.

\section{Retrolental fibroplasia (RLF)}

This oxygen-induced retinopathy occurring in premature babies may result either in total bilateral retinal detachment or in minor degrees of detachment, as, for instance, in falciform retinal detachment. While the pathogenesis of this disease has been demonstrated to originate with destruction of the immature retinal vessels by oxygen, first in animals (Ashton, Ward, and Serpell, 1953) and later in premature babies (Ashton, I966), the 
mechanism of the vasoproliferation, which follows on return to normal air, is still not fully understood. It is thought, however, that the main condition governing new vessel growth in the retina is hypoxia (Ballantyne and Michaelson, 1970). According to Ashton (I96r), three conditions favour vasoformation: the presence of living tissue, low oxygen saturation, and poor venous drainage, the last resulting in the accumulation of a metabolite or vasoformative factor released from the hypoxic cells. It is likely, therefore, that retinal neovascularization arises in widely differing conditions.

Some authors have expressed their belief that RLF occurs in full-term infants (Reese, I949; Reese and Blodi, I95I ; Unsworth, I949; Dixon and Paul, I95I) and in premature infants unexposed to oxygen (Brückner, I968). In explanation it has been suggested, on the one hand, that the degree of maturity of the retinal vessels almost certainly varies in the full-term baby, and, on the other, that the normal physiological rise in oxygen tension from 50 to 90 per cent. may in some cases be sufficiently toxic without oxygen therapy. Brückner (1968), who reported bilateral RLF in a premature baby who had not received oxygen, thought the condition might be due either to hypoxia during intrauterine life from severe iron deficiency anaemia in the mother, or to a reactive polycythaemia in the child leading to an exaggerated oxygen saturation at birth, which then caused vaso-obliteration of the retinal vessels.

Whether general hypoxaemia alone, through changes in the haemopoietic or haemodynamic system of the mother, or through reduced perfusion in an abnormal placenta, or through pathological changes in the foetus itself, can give rise to neovascularization is questionable; experimental work is either in favour (Mizukawa, I955) or against (Ashton, Ward, and Serpell, 1954; Gyllensten and Hellström, 1955; Patz, I955). It is interesting to note, however, that 23 of 37 children, who at birth or in the first days of life had suffered with hypoxaemia of sufficient severity to give rise to optic atrophy and widespread damage to the central nervous system, had no retinal vasoproliferative changes (Fraser and Friedmann, 1967). But if hypoxia of a certain degree is associated with impairment of the venous drainage the circumstances for new vessel growth would be ideal, and such situations could arise in many ways of which vaso-obliteration (after oxygen exposure for instance) is only one.

With regard to our own cases, the localization of a mass on the nasal side argues against a relationship with an "immature retina", which in a full-term infant would be expected on the temporal side. Moreover, if we accept the term RLF as occurring only in premature babies and caused by oxygen, then none of our cases can strictly be classified here, although the histological appearances were strikingly similar, particularly in Case I 2 (Figs I and 2) in Group B, and in Case 3 (Fig. 3), Case 8 (Fig. 4), Case 9 (Fig. 5), and Case ro (Figs 6 and 7) in Group A.

Coats's disease (External exudative retinitis, telangiectasis of the retina)

This congenital eye disorder is usually unilateral, mainly affects males, and is characterized clinically by extensive exudates in the fundus, often with microaneurysms and dilated vessels. The disease is said to be rare in infants, but in the Department the collection of eyes from such cases contains 22 examples (about ro per cent.) from infants under I year old. There was only one case with bilateral involvement and the ratio of males to females was 3.5 to I. Four of them showed abnormal eye signs during the first 2 months after birth, and signs appeared in the others after 6 months of age. The histological changes in these eyes were typical of the condition. 


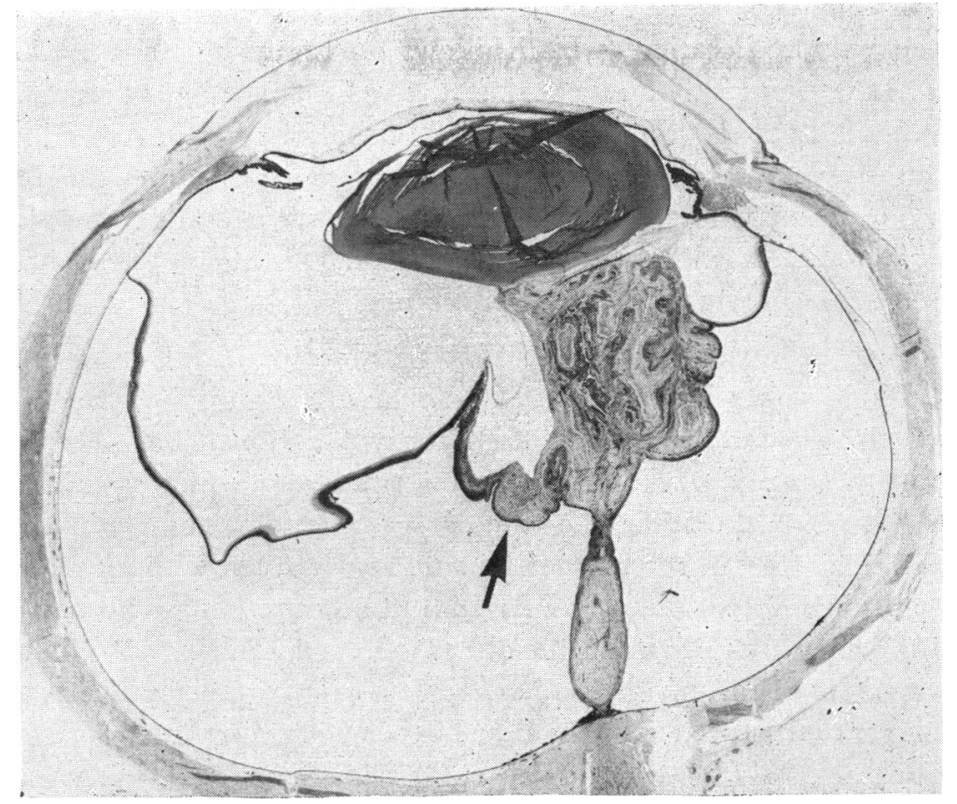

FIG. I Case 12. Section of right eye, showing in one half of the globe a detached and folded retina adherent to the posterior surface of the lens, while in the opposite side of the globe, the retina is more shallowly detached. Haematoxylin and eosin. $\quad \times 6$

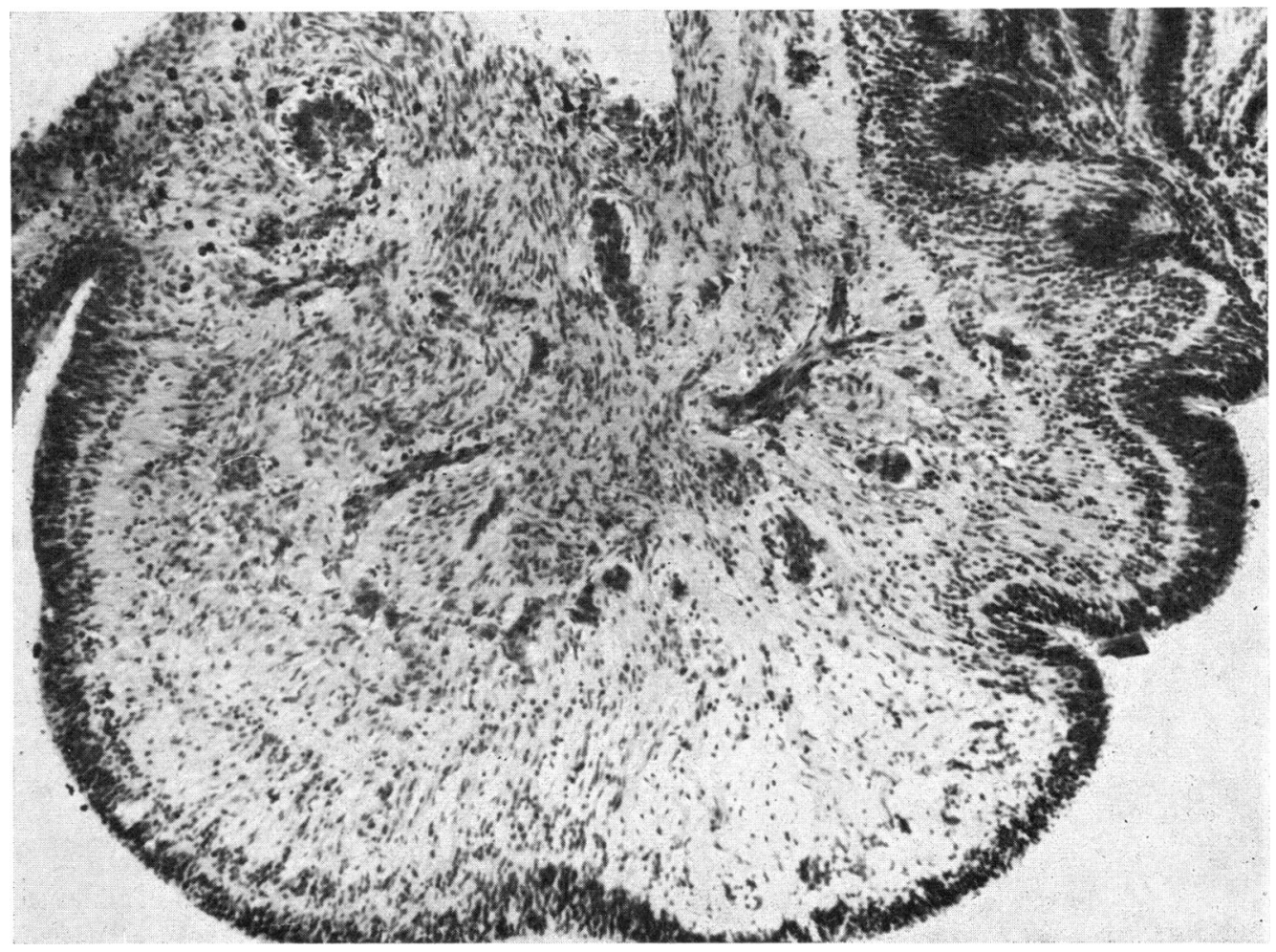

FIG. 2 Case 12. Portion of detached retina, showing intraretinal neovascularization (Arrowed, Fig. I). Haemaioxylin anl eosin. $\times 100$ 


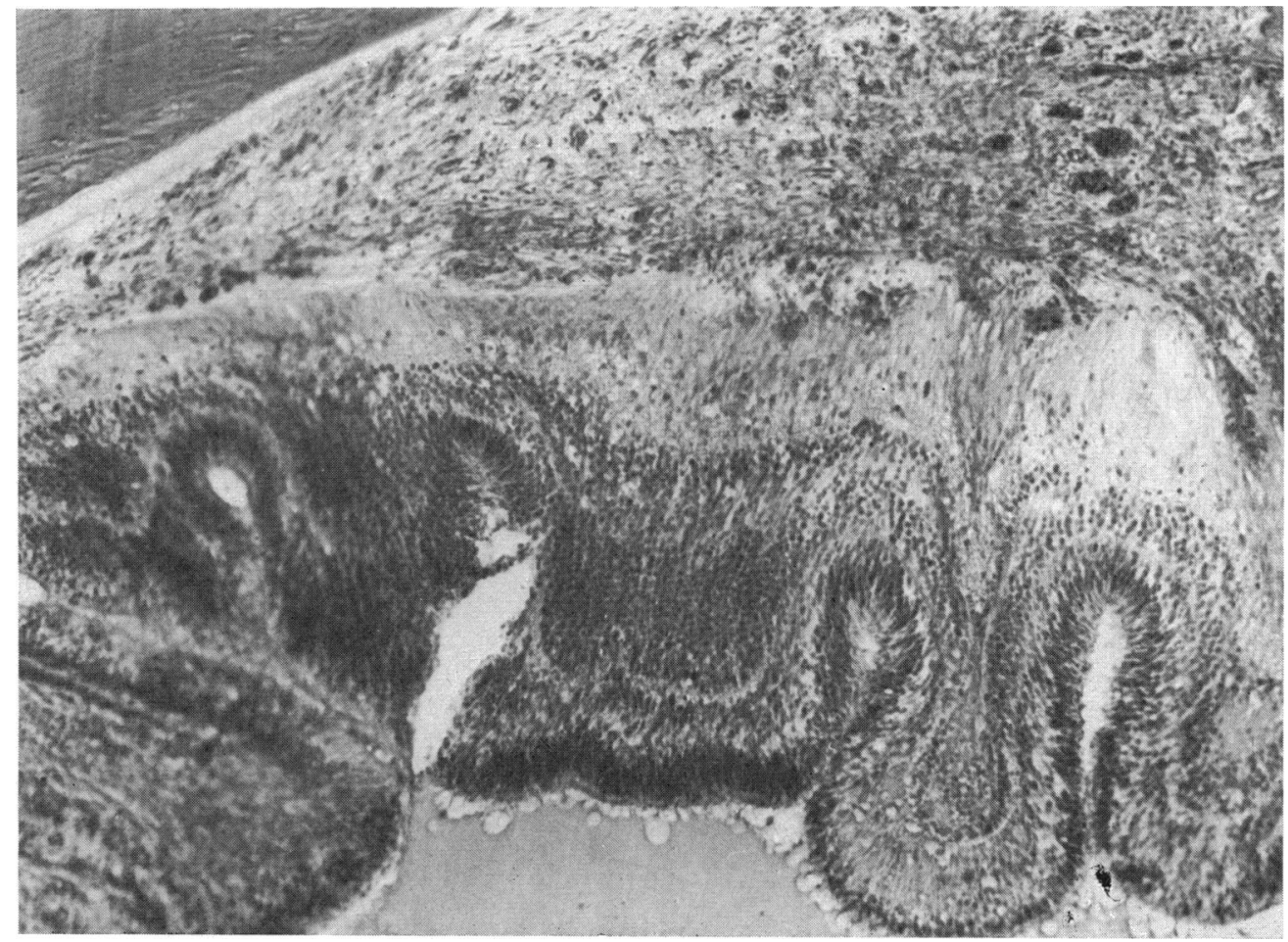

FIG. 3 Case 3. Neovascular tissue extending from detached retina to posterior surface of lens. Haematoxylin and eosin. $\times 100$

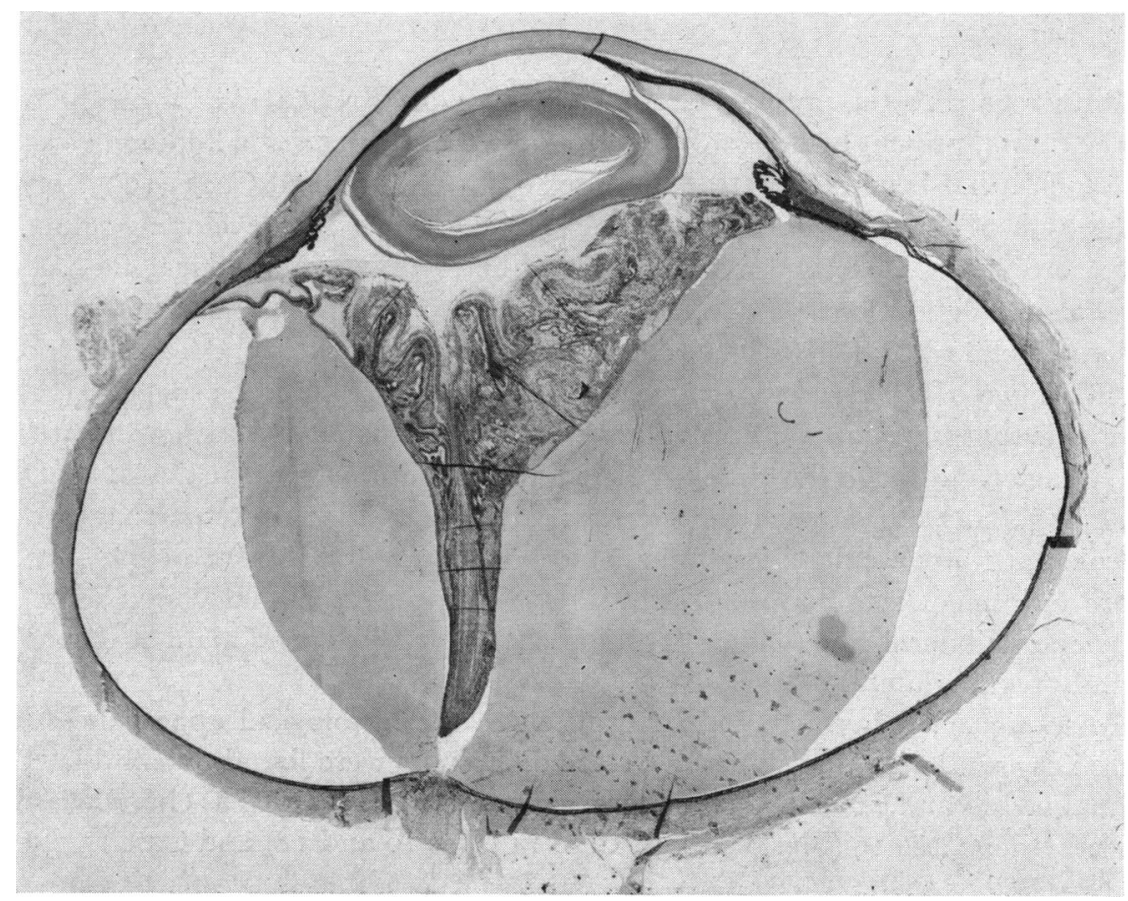

FIG. 4 Case 8. Section of eye, showing stalk-like retinal detachment, preretinal neovascularization, and complete obliteration of anterior chamber. Haematoxylin and eosin. $\quad \times 6$ 


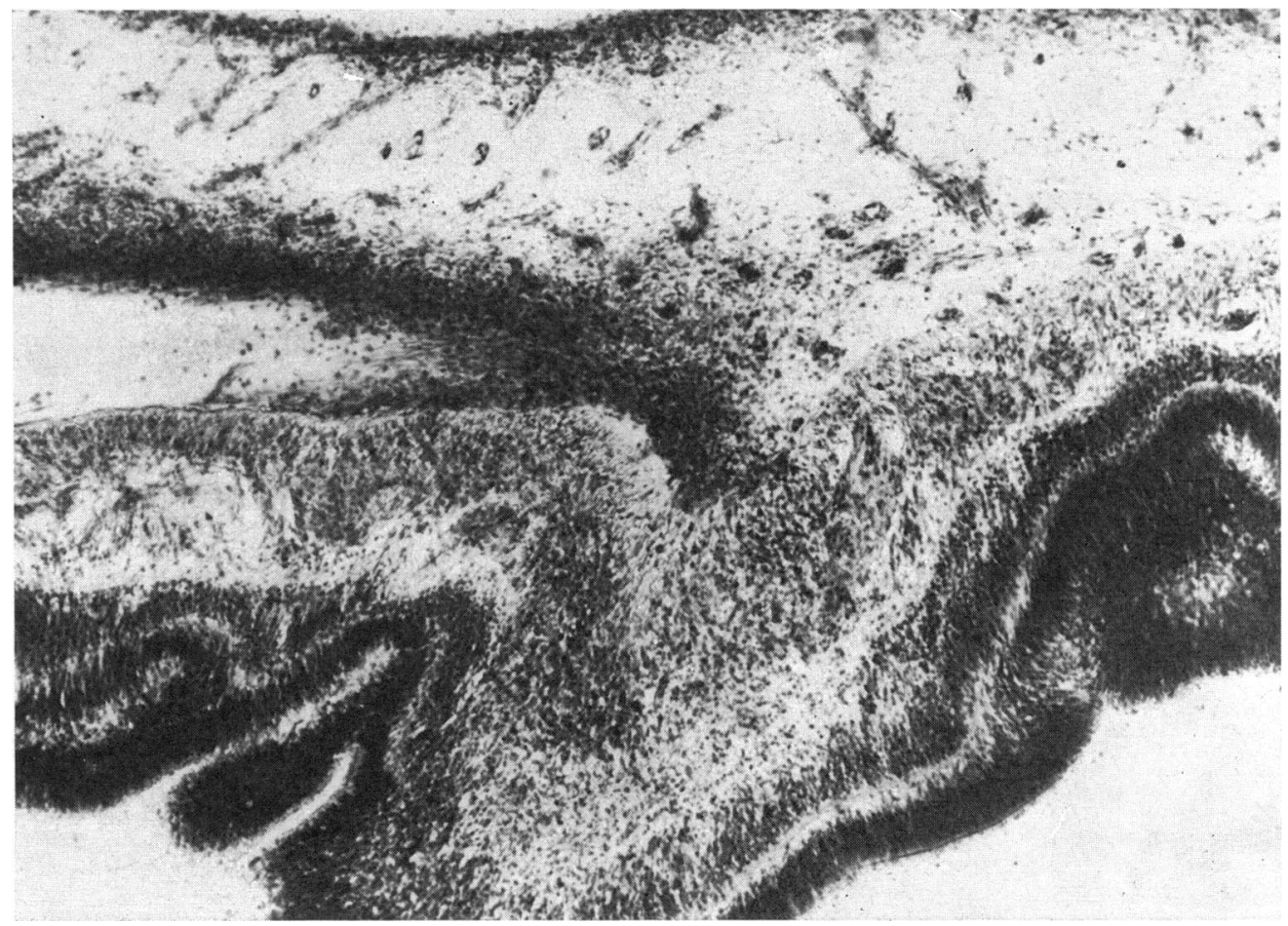

FIG. 5 Case 9. Portion of detached retina, showing neovascular tissue extending from retina into vitreous. Haematoxylin and eosin. $\times 75$

With regard to the present series, the outgrowth of retinal vessels on the outer surface of the retina, present in many of our cases, is not a characteristic finding in Coats's disease, although it has been demonstrated (Wise, I96I). Ashton and Cook (I955) produced such outgrowth of new vessels in kittens simply by detaching the developing retina.

According to Duke and Woods (1963), the essential pathological findings in Coats's disease are depositions of cholesterol and an unidentified crystalline substance in the external retina together with fatty acids in the subretinal space. As these depositions were found in two of our cases, the diagnosis of Coats's disease could be suggested, although it is probable that such deposits are evidence only of chronic blood leakage and are non-specific in character. Although the histology of our cases was quite similar to that of the Department's series in infants, our sections showed more extensive preretinal haemorrhages, more marked retrolental fibrovascular membranes, more frequent detachment of the pars plana, and more prominent retinitis proliferans. Dilated peripheral retinal vessels were observed in only one unilateral case, while subretinal cholesterol clefts and giant reactions were found in only two unilateral cases.

In summary, it is concluded that, although the histological appearances in our series were very similar to Coats's disease, some differences were found, but if dilated peripheral retinal vessels and subretinal cholesterol clefts are to be regarded as characteristic of Coats's disease, then Case I 3 (Figs 8 and 9), Case I4 (Figs Io and I I) and Case I5 (Fig. I2) could be classified as such.

Falciform retinal detachment (FRD)

This unilateral or bilateral disorder widely known through the papers of Mann (I935) and Weve (1935, 1938) affects both sexes and may be familial. Usually the fold extends 


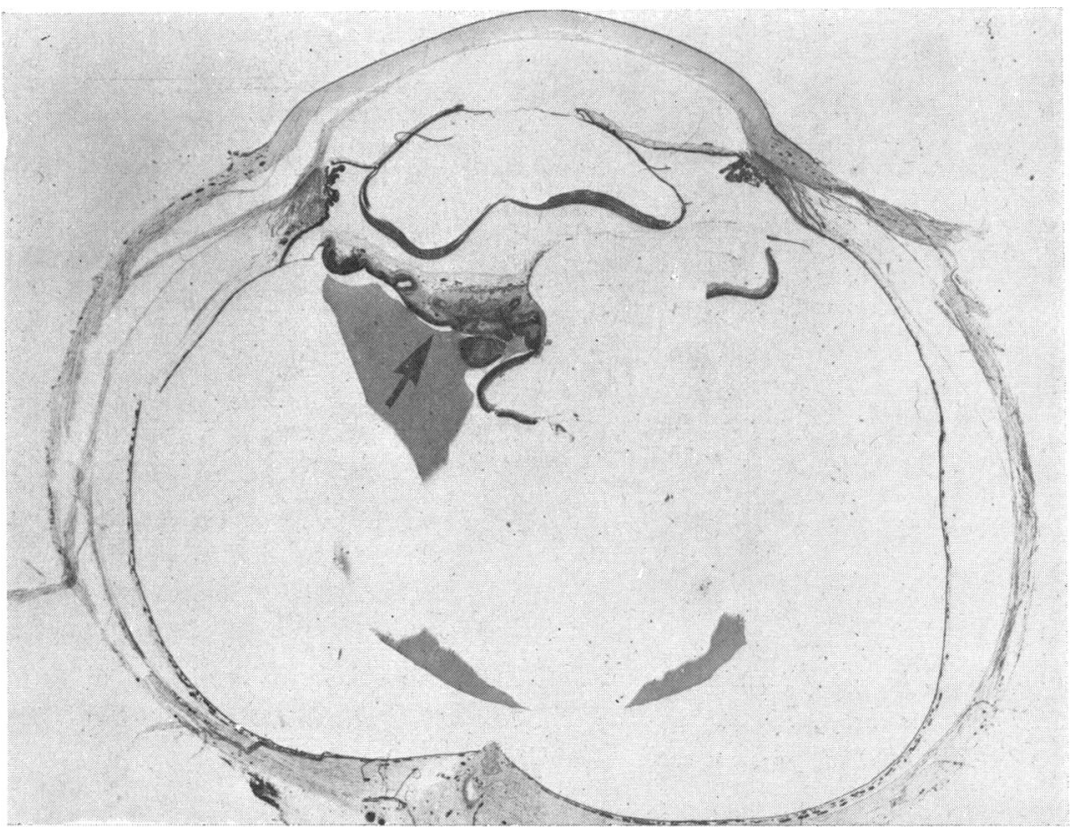

FIG. 6 Case I0. Section of left eye, showing total retinal detachment and retinitis proliferans. Haematoxylin and eosin. $\quad \times 6.5$

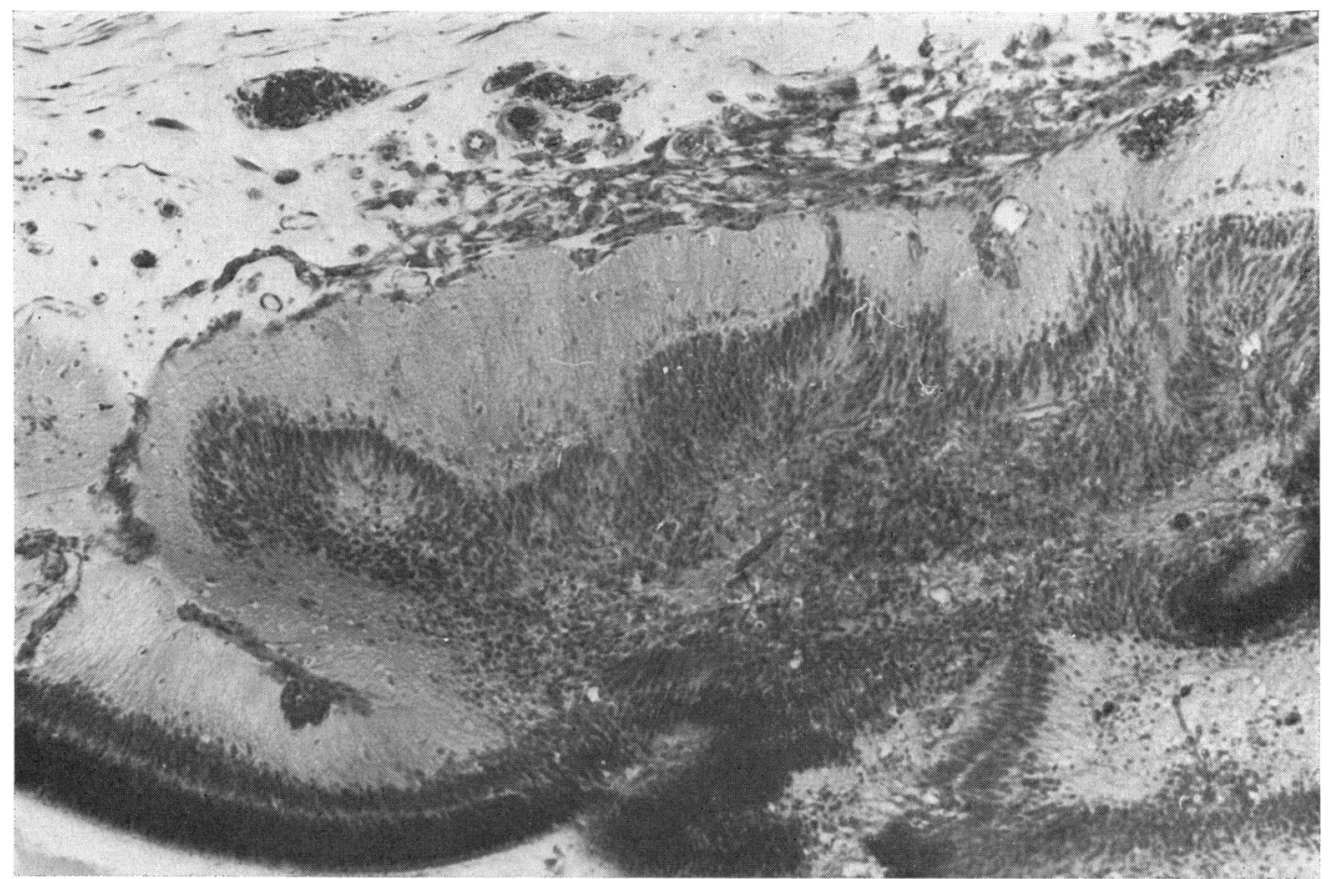

FIG. 7 Case 10. Portion of detached retina, showing neovascular tissue on inner retinal surface (Arrowed, Fig. 6). Haematoxylin and eosin. $\times$ roo 


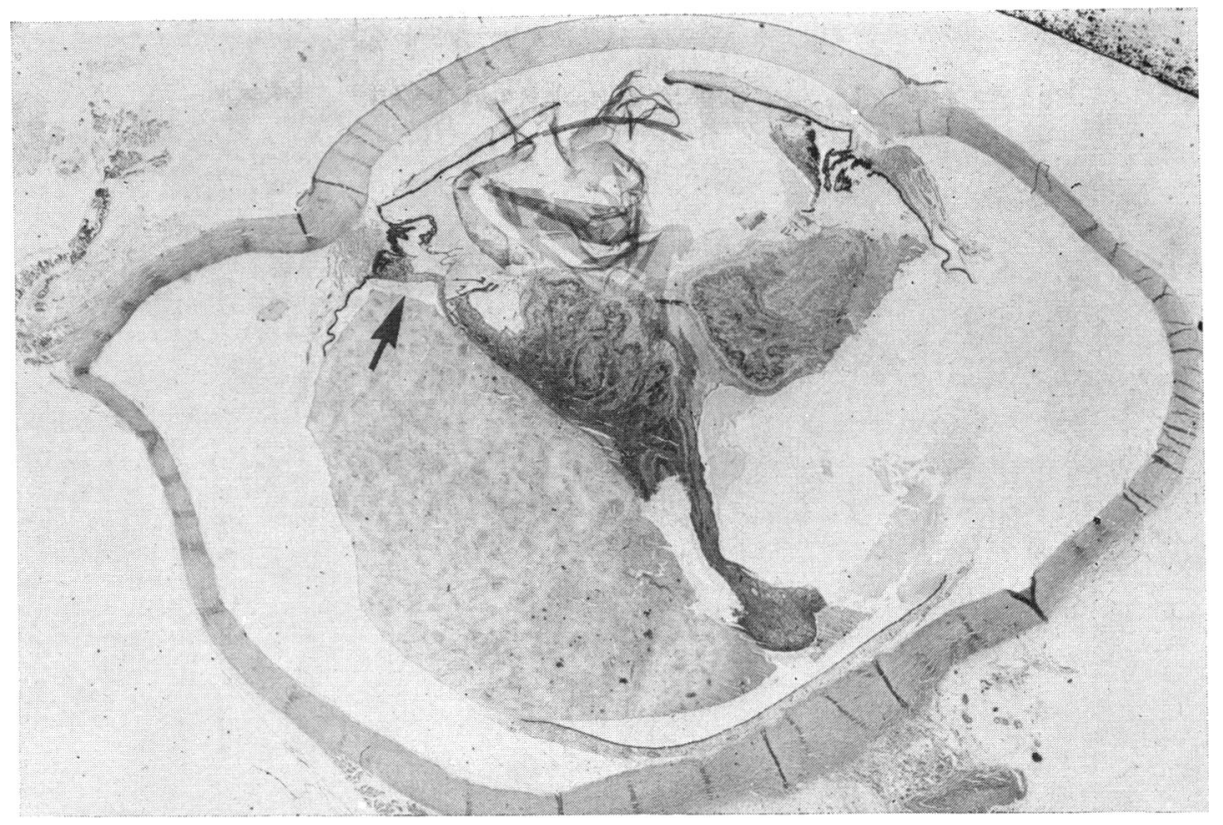

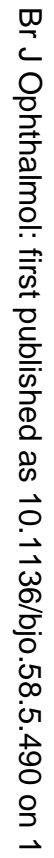

FIG. 8 Case I3. Section of left eye, showing stalk-like retinal detachment and cholesterol clefts in subretinal albuminous exudate. Haematoxylin and eosin. $\quad \times 6 \cdot 25$

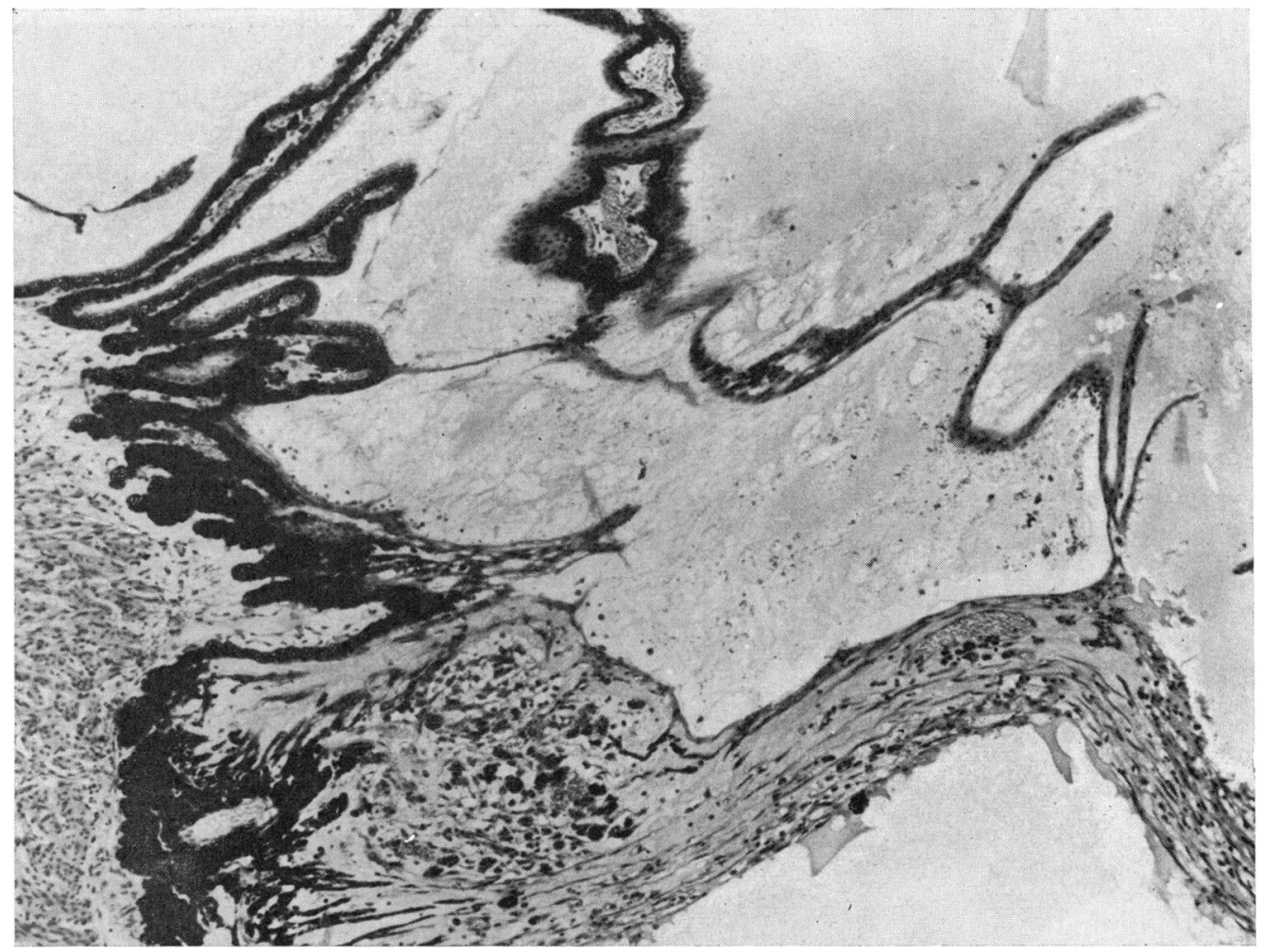

FIG. 9 Case 13. Proliferation of unpigmented epithelium and portion of detached, degenerate, and gliosed retina with intraretinal haemorrhage and some new-formed capillaries (Arrowed, Fig. 8). Haematoxylin and eosin. $\times 6_{5}$ 


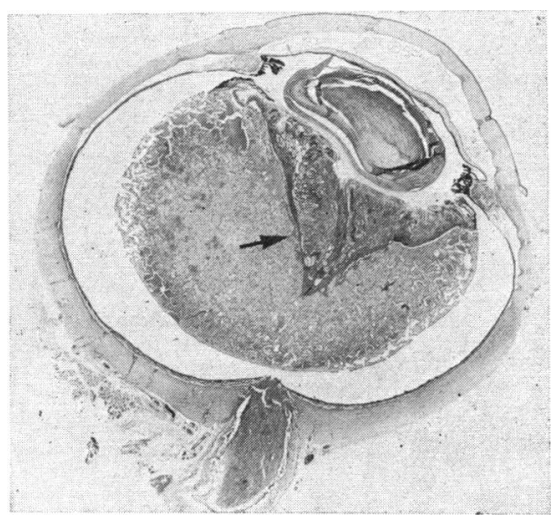

FIG. Io Case 14. Section of left eye, showing total retinal detachment with detachment of pars plana epithelium and cholesterol clefts in subretinal space. Haematoxylin and eosin. $\quad \times 3$

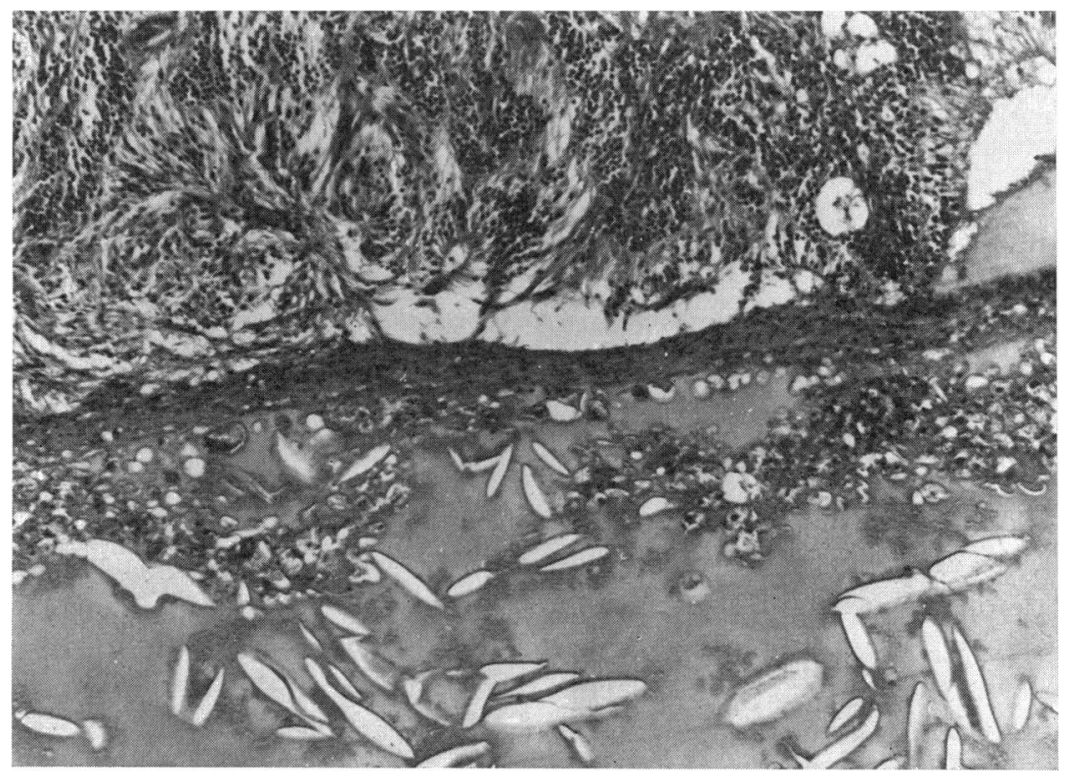

FI I. I Case I4. Subretinal exudate, showing cholesterol clefts and lipid macrophages (Arrowed, Fig. 10). Haematoxylin and eosin. $\times 75$

from the optic disc to the temporal periphery and is associated with persistent hyaloid vessels. Total retinal detachment on one side and FRD on the other is not infrequent (Weve, I938; Poulsen, I947; Warburg, I966: Case T.H.R.). Von Barsewisch (1969) reported atypical cases of FRD in which the fold reached the nasal periphery of the fundus, even bilaterally. Abnormal vitreous adhesions to the inner layer of the optic cup were suggested as a cause of FRD by Mann (1935), and this is supported by the experimental work of Orts Llorca and Genis Galvez (1960). Badtke (1960), who studied Degenhardt's material (the offspring of pregnant rabbits kept in hypoxia), found several eyes with retinal folds, duplication of the retina, and coloboma: he therefore suggested that several noxae during intrauterine life could result in FRD.

It is well known that retinal folds of this type can be observed in RLF Stage II and have been described in congenital toxoplasmosis (Dekking, I949). Haemorrhages and exudates similar to Coats's disease have been described with FRD (Bardelli and Molinelli, I968), and new-formed retinal capillaries were seen in the cases of Weve (1938) and Heydenreich 


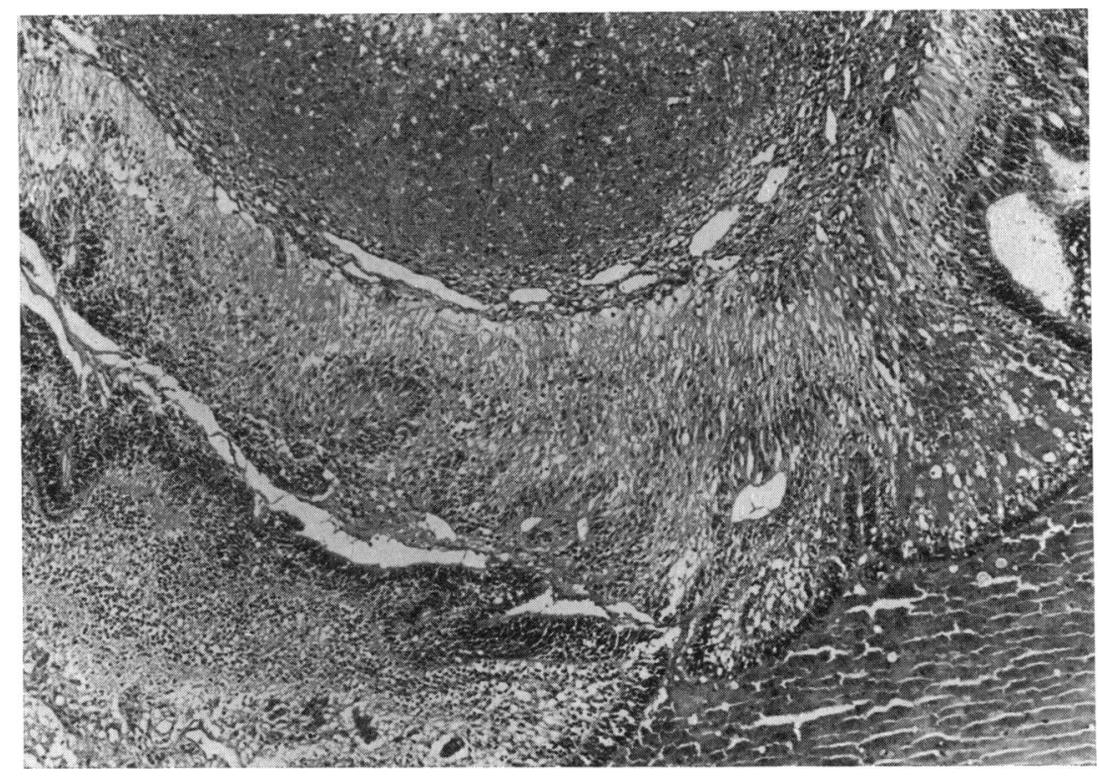

FI G. I2 Case I5. Portion of the detached retina with preretinal dilated capillaries surrounding extensive area of preretinal haemorrhage. Haematoxylin and eosin. $\times 54$

(1959). These and other described histological features in FRD were also present in our cases, but seven cases of FRD from the material of the Department differed in that haemorrhages and vasoproliferation were less prominent. In three of our cases (Cases 4,7 , and 12), the diagnosis of FRD must especially be considered. Histologically, Cases 4 and 7 (Figs I 3 to I 7 ) showed, besides retinal detachment and retinitis proliferans (most prominent in Case 4), peripheral anterior synechiae, cataract, proliferation of the pigment epithelium, preretinal and subretinal haemorrhages, duplication of the retina, indrawn optic nerve (only Case 7), and vitreo-retinal tufts. Most significantly the fellow eye of Case 4 showed clinically a retinal sheet and that of Case 7 retinal folds. Case 12, already mentioned as resembling RLF except that the pathological changes were on the nasal side, was very similar to Case 7 (compare Figs I and I5). On one side there was a convolution of folded and gliosed retina (with true rosettes) attached to the lens by a fibrovascular membrane, while on the other side the retina was more shallowly detached. There were also suband intraretinal haemorrhages, vitreal strands, glomeruloid endothelial buds, and vasoproliferation.

The association of FRD with hypogenitalism and cryptorchism in two brothers of normal intelligence was reported by Mackensen (1953). Our Case 6 is similar, in that the child was of normal physical and mental development, having, besides bilateral leucocoria, small testicles, but since there was no evidence of a retinal fold (Fig. I8) the case cannot be assigned to this group.

FIG. I3 Case 4. Section of left eye, showing duplication of retina starting beyond the ora serrata and continuing anteriorly onto a mass of folded and degenerate retina adherent to the lens by a fibrovascular membrane. There is proliferation of the pigmented and non-pigmented ciliary epithelium. Haematoxylin and eosin. $\quad \times_{4}$

FIG. I4 Case 4. Portion of detached retina, showing preretinal haemorrhage and vasoproliferation (Arrowed, Fig. 13). Haematoxylin and eosin. $\times 95$ 

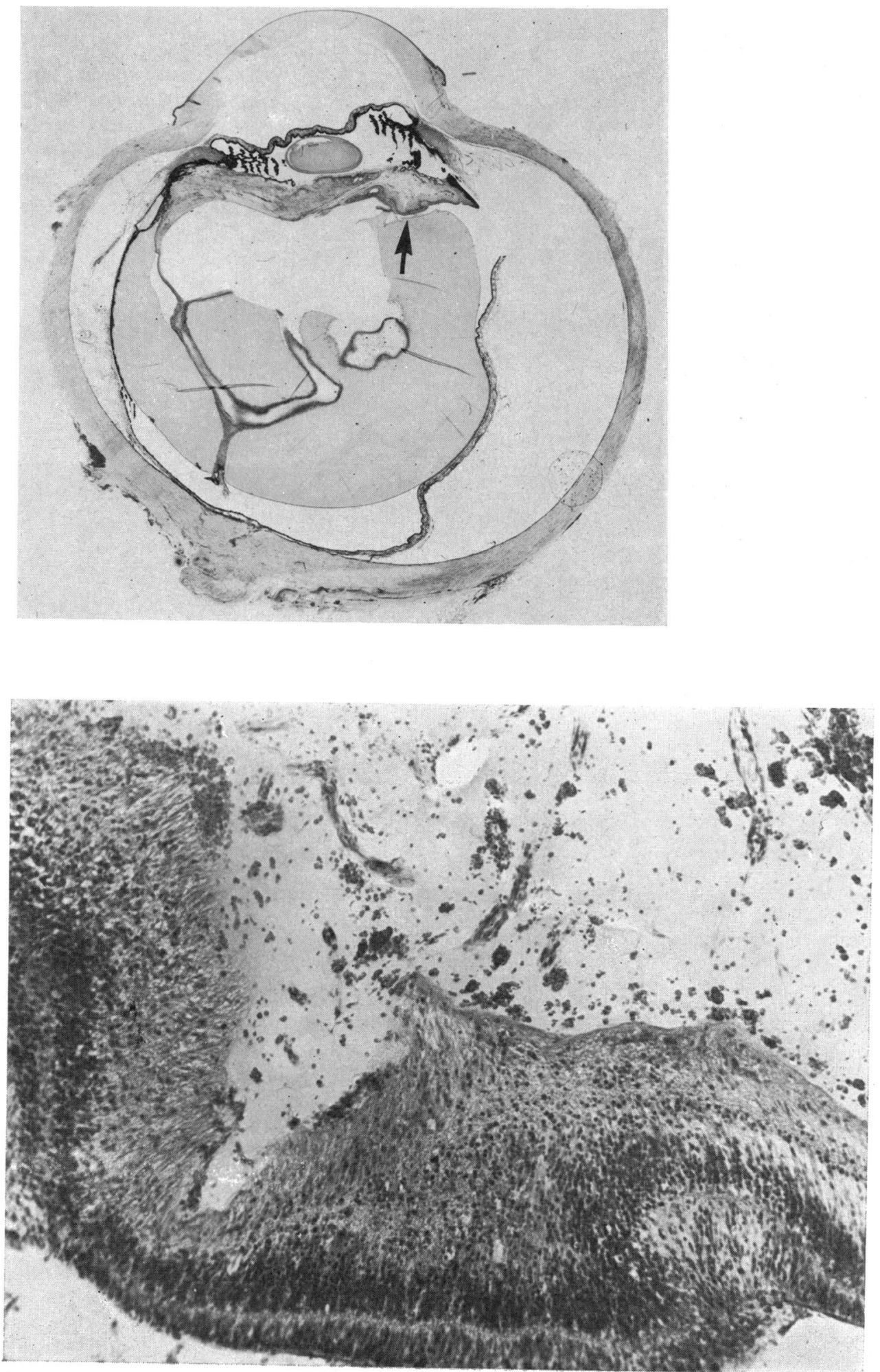


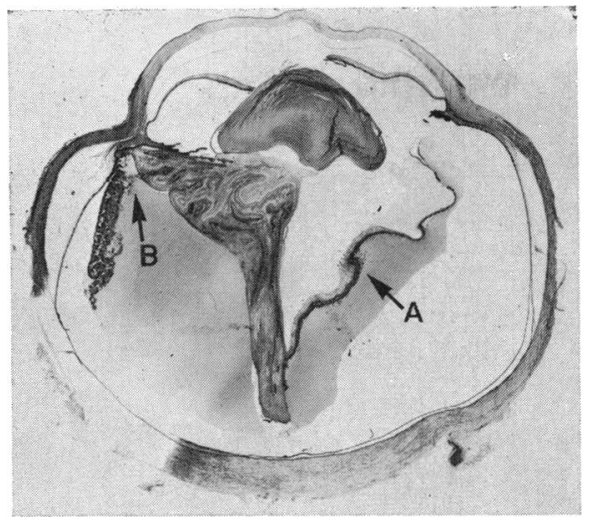

FIG. I5 Case 7. Section of right eye, showing in one half of the globe a mass of detached, folded retina adherent to the posterior surface of the lens through a fibrovascular membrane, while in the other half the retina is more shallowly detached with vitreo-retinal tufts on the inner surface. Haematoxylin and eosin. $\times 3.5$

FI G. I6 Case 7. Portion of detached retina, showing vitreo-retinal tufts on surface (Arrow A, Fig. I5). Haematoxylin and eosin. $\times 75$

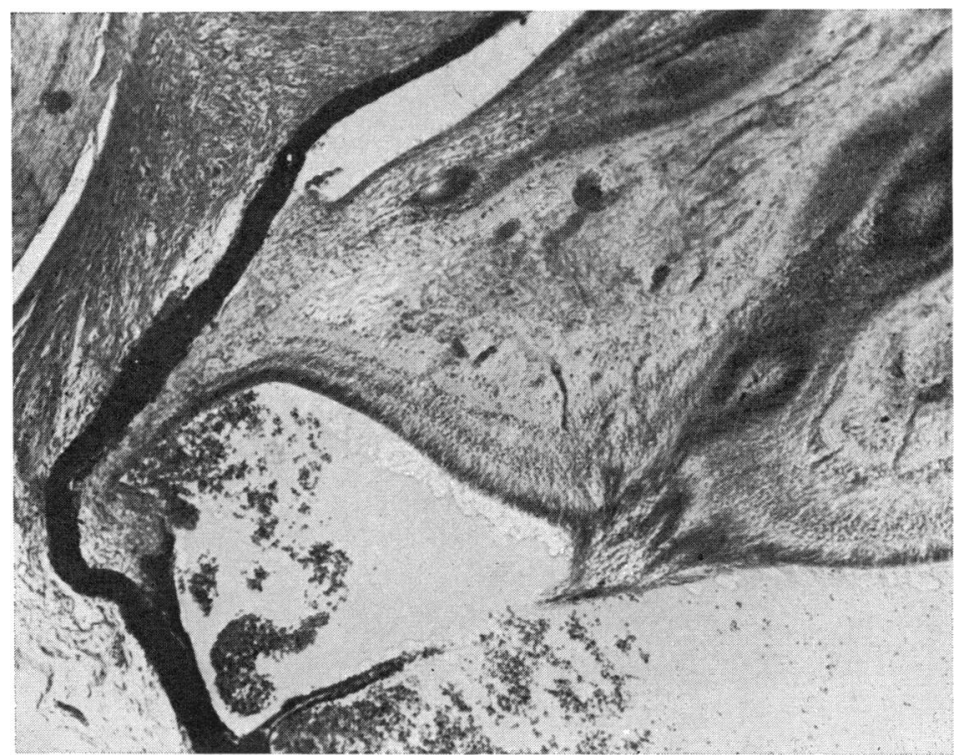

FIG. I 7 Case 7. Detachment of pars plana epithelium and subretinal haemorrhage. Detached portion of retina? shows a moderate degree of neovascularization (Arrow B, Fig I5). Haematoxylin and eosin. $\times 54$ 


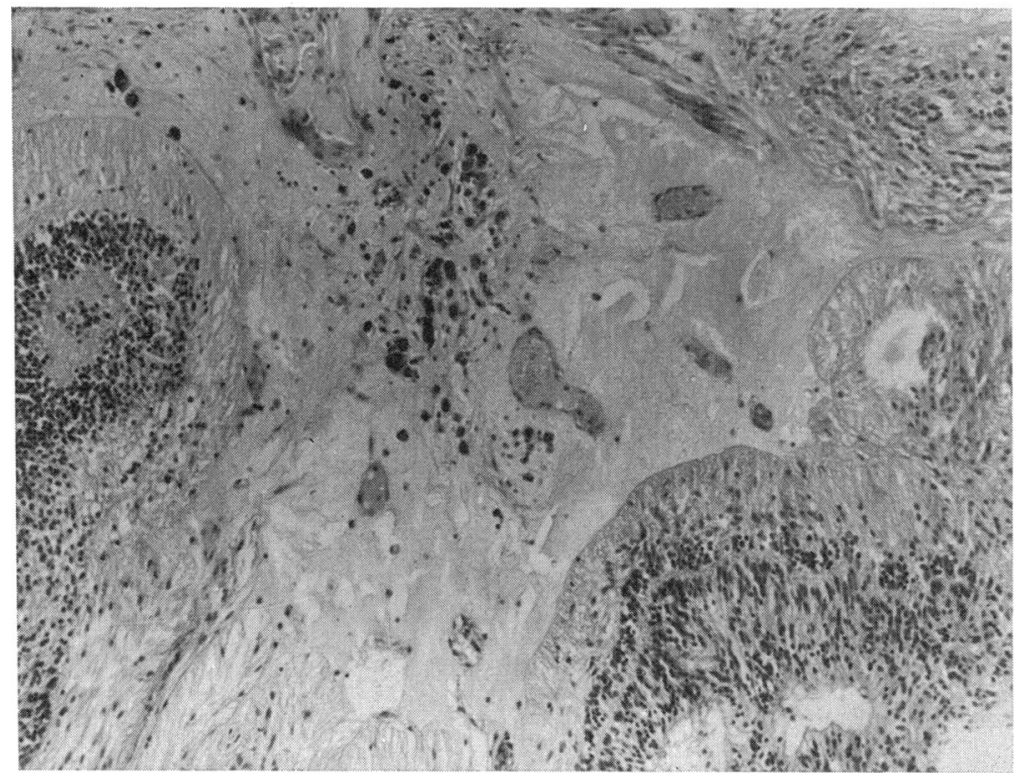

FIG. 18 Case 6. Portion of detached retina, with haemorrhage and neovascular tissue extending from retina into vitreous. Haematoxylin and eosin. $\times 86$

In summary, it is concluded that clinical and histopathological observations favour the classification of our Cases 4, 7, and 12 as possible examples of falciform retinal detachment.

\section{Retinal dysplasia}

This is a histological abnormality and should be diagnosed only in the presence of typical round or oval rosettes (Hunter and Zimmerman, 1965). When unilateral in malformed eyes it is usually not associated with extraocular abnormalities, whereas bilateral retinal dysplasia, which may be inherited, usually is (Reese dysplasia, I3-15 trisomy) but not always so (Hunter and Zimmerman, 1965). True rosettes resulting from malformation and disorganization of the retina, were found in three of our bilateral cases and three unilateral, but with such sparsity that the diagnosis of retinal dysplasia was hardly justified. Compared with three cases of I $^{-1} 5$ trisomy and eighteen cases of retinal dysplasia in the Department files, the histological features were quite different and none of our cases could be classified in this category.

Norrie's disease (congenital progressive oculo-acoustico-cerebral degeneration)

This clinical entity affects males only: leucocoria is the presenting sign, occurring usually at birth but sometimes within the first 2 years of age (Warburg, I966). The pathogenesis is unknown, but Warburg ( 1966 ) suggested that the change must be due to a malformation at the Io-1 $7 \mathrm{~mm}$. stage in embryonic life ( $5^{\text {th }}-6$ th week). Clinically there were yellowishwhite retrolental vascular membranes, vitreous haemorrhages, extension of the ciliary processes, frequently ectropion uveae, and synechiae of the iris. Microphthalmos according to Warburg (1965) is absent at birth, although she suggested the diagnosis of Norrie's disease in a family with hereditary cataracts and microphthalmia described by Capella, Kaufman, Lill, and Cooper ( 1963 ). 
Histologically, Norrie's disease may closely resemble or show features similar to Coats's disease (Blodi and Hunter, 1969), to incontinentia pigmenti (Scott, Friedmann, Chitters, and Pepler, I955), to RLF (Findlay, I952), and to FRD (Cole and Cole, I959). The brother and cousin (mother's sister's son) of our Case 5 showed leucocoria in both eyes and mental retardation. This case has been previously briefly described (Forrester, 1963: Case 4; Fraser and Friedmann, I967: Case C2), and Warburg (1966) considered it to be an example of Norrie's disease. We now know that both brothers also show stunted growth, which to our knowledge has not been described in this disease. The histology of the enucleated eye (Fig. 19) showed total retinal detachment with preretinal and subretinal haemorrhages. The detached and gliosed retina showed regularly distributed new-formed capillaries and was adherent to the lens by a dense fibrous membrane (Fig. 20): the whole complex of detached retina and retrolental tissue had pushed forward the iris and lens, occluding the chamber angles. Remnants of the pupillary membrane were present.

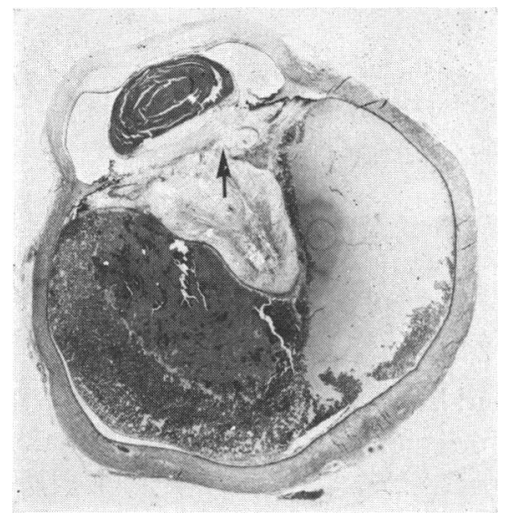

FIG. 19 Case 5. Section of left eye, showing total retinal detachment, detachment of pars plana epithelium, subretinal haemorrhage, and new-formed capillaries distributed regularly. There is a dense fibrous membrane posterior to the lens and the iris adherent to the posterior surface of the cornea. Trichrome stain. $\times 3$

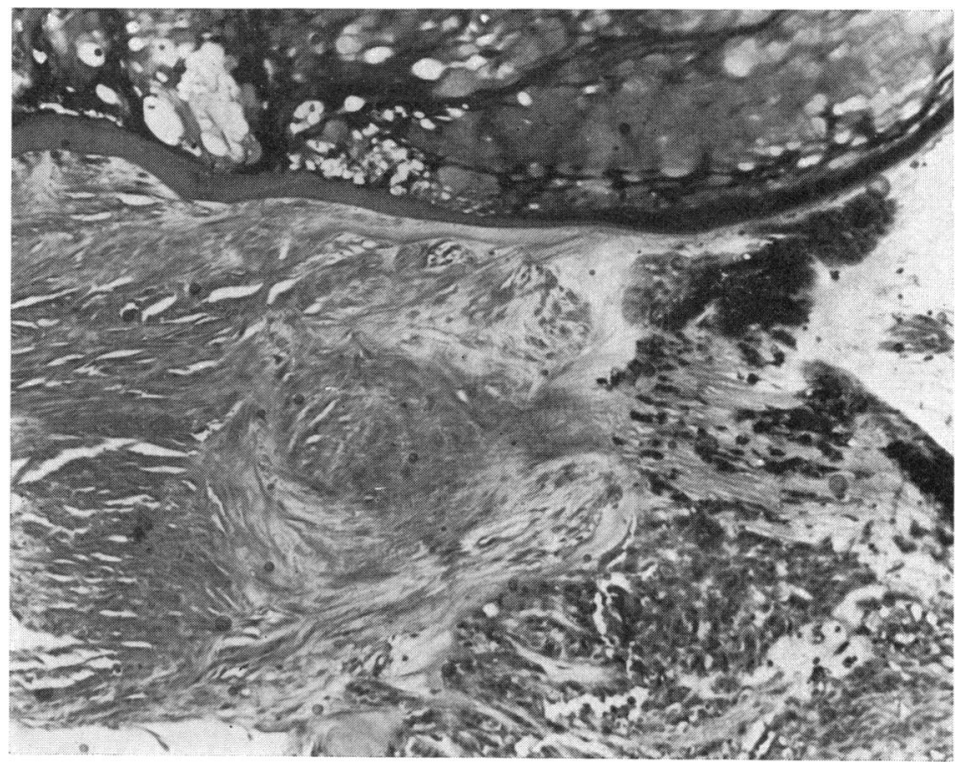

FIG. 20 Case 5. A dense fibrous membrane is present behind the cataractous lens (Arrowed, Fig. 19). Trichrome stain. $\times 86$ 
This case, which in our view does not completely fit into the group of Norrie's disease, will be mentioned again later with other cases from the literature associated with bone disorders.

\section{Retinal detachment and intraocular haemorrhage due to trauma}

Bilateral retinal detachment, intraocular haemorrhages, retinitis proliferans, and massive retinal fibrosis have been attributed to birth trauma from forceps delivery (Lachman, 1927; Reese, I936). In two of our cases such a cause might be applicable. In our unilateral Case 14, resembling Coats's disease, forceps delivery was reported, and in our bilateral Case Io a Caesarian delivery was carried out because of breech presentation and foetal distress. The histology was very similar to RLF and hypoxia of the foetus could be suggested as a factor in pathogenesis. At the age of 3 weeks it was noticed that Case ro had long fingers, but he showed normal development and no other abnormalities were noticed in either the child or the family. It is questionable whether the long fingers had any relation to the ocular condition, although retinal detachment in association with Marfan's syndrome has been reported (Fischbach, I937; Fraser and Friedmann, I967: Case M 29).

\section{Battered baby syndrome}

Kiffney (1964) was the first to describe ocular involvement in this syndrome-intraocular haemorrhages, retinal detachment with multiple fractures of the skull. Interestingly, a case of battered baby syndrome described by Mushin and Morgan (197I) was first misdiagnosed as Coats's disease. Our bilateral Case 9 was suggested by the clinician to be an example of this syndrome as the child had a head injury at the same time and social problems in the family were known. Histologically, the enucleated eye showed hyphaema, recent pre-, intra-, and subretinal haemorrhages, and a prominent retinitis proliferans (Fig. 5). It was also reported that the younger brother of the child had an unusual facial appearance with hypertelorism and anisocoria, similar to that of his mother, which might reflect some familial cranio-facial disorder. It might be, therefore, that the ocular condition was either unrelated to, or only aggravated by, trauma.

\section{Congenital retinal detachment due to inflammation during intrauterine life}

In only four of our cases were inflammatory cells found; these were very few and regarded as secondary. One of these (Case 3) had a doubtful positive toxoplasmosis test, so that this diagnosis cannot be ruled out, although the histology of the eye showed prominent vasoproliferation (Fig. 3), which has not been described in toxoplasmosis. However, pseudoglioma with a raised toxoplasmosis titre (Fraser and Friedmann, I967, Case PI3) and FRD in congenital toxoplasmosis (Dekking, 1949) have been reported.

\section{Chromosomal aberrations and teratogenic agents}

The different clinical manifestations in our cases, such as microphthalmos, syndactyly, abnormally long fingers, and abnormally small testicles, are found with chromosomal aberrations, but are not characteristic of any special type (François, Berger, and Saraux, I972) although retinal detachment is usually related to myopia or retinal dysplasia (13-I5 trisomy). The phenotype reported in our cases did not signal any known chromosomal aberration. The chromosomal pattern of Case 5, thought to be a sex-linked inherited disorder, has already been described (Table III), while that of Case 9, the brother of which had hypertelorism and anisocoria, was reported as normal in the follow-up. 
Old age of the mother was reported in our bilateral Case I, suggesting the possibility of spontaneous mutation. The child later developed deafness but otherwise showed normal physical and mental development. His four normal siblings had no relevant ocular abnormalities. The combination of bilateral leucocoria and deafness in this case reminds one of Norrie's disease, but as there are no ocular abnormalities in the family this diagnosis is not justified. Histologically, the enucleated eye (Figs 2 I to 23) showed preretinal haemorrhages, a membrane of proliferating vessels in the periphery of the retina on one side and an encysted haematoma posterior to the lens. Old age of the mother has been documented in $\&$ cases of pseudoglioma (Fraser and Friedmann, I967: Gi I, I 5, I 7) and retinal dysplasia $\overrightarrow{0}$ (A I 3, 2 I , 37, 42, 45, 55, 57), while FRD has been described in mongolism (von Pelláthy, I93 I) in which old age of the mother is a factor. It may also be recalled that in mongolism there is a tendency to hypoplasia of the vascular system.

Rubella virus and thalidomide are known human teratogenic agents. It is interesting that the eye of a thalidomide child (case of the Department) showed marked retinitis or

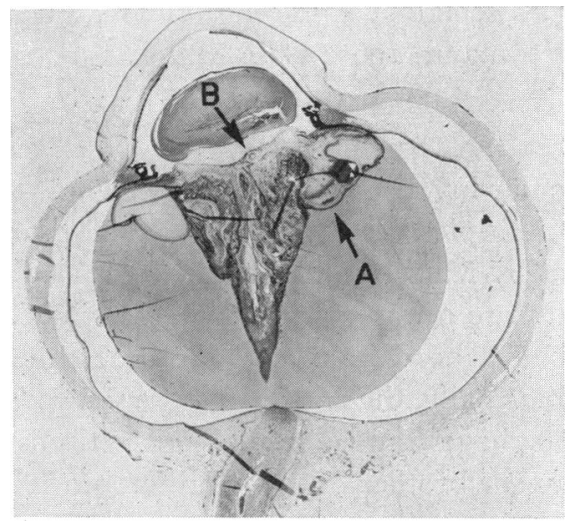

FIG. 2 I Case I. Section of right eye, showing total retinal detachment and formation of rosettes with preretinal haemorrhages and a membrane of proliferating vessels in the peripheral retina on one side. The iris adheres to the posterior surface of the cornea. Haematoxylin and eosin. $\quad \times 4.5$

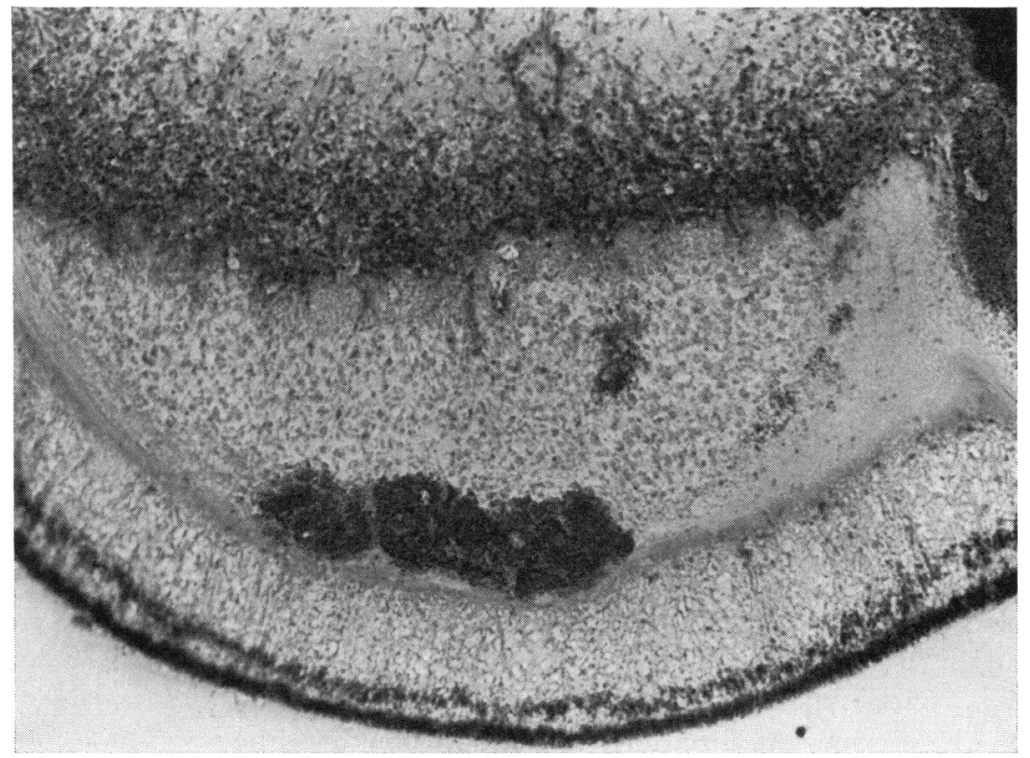

FI G. 22 Case I. Portion of detached retina with preretinal haemorrhage and neovascular tissue (Arrow A, Fig. 2 I). Haematoxylin and eosin. $\times 86$ 


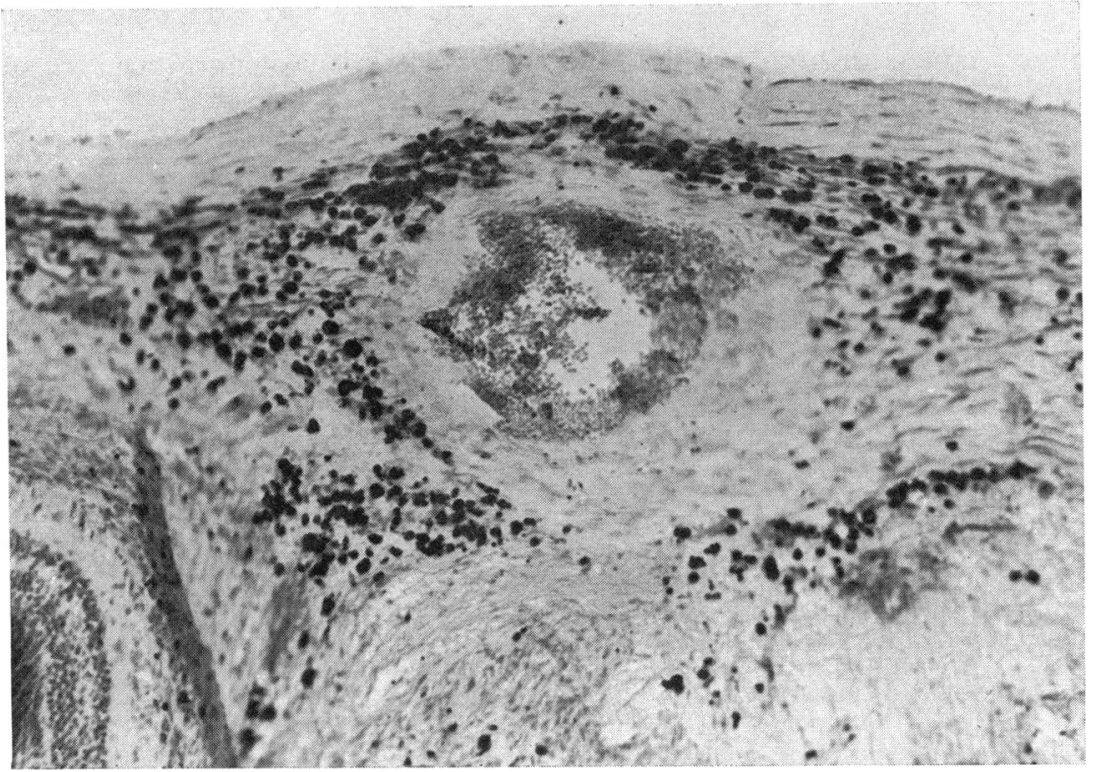

FIG. 23 Case I. Encysted haematoma in preretinal tissue behind posterior surface of lens (Arrow B, Fig. 2 I). Haematoxylin and eosin. $\times 90$

proliferans histologically. Influenza in pregnancy has been incriminated in cases of retinal dysplasia, in nonfamilial pseudoglioma, coloboma, microphthalmos, and cataract (Fraser and Friedmann, 1967). Among our cases which might reflect the action of a teratogenic agent are:

(I) Case 2 (retinal detachment and retinitis proliferans) because the mother had influenza in the eighth week of pregnancy. There was, however, no evidence of inflammation in this eye (Fig. 24).

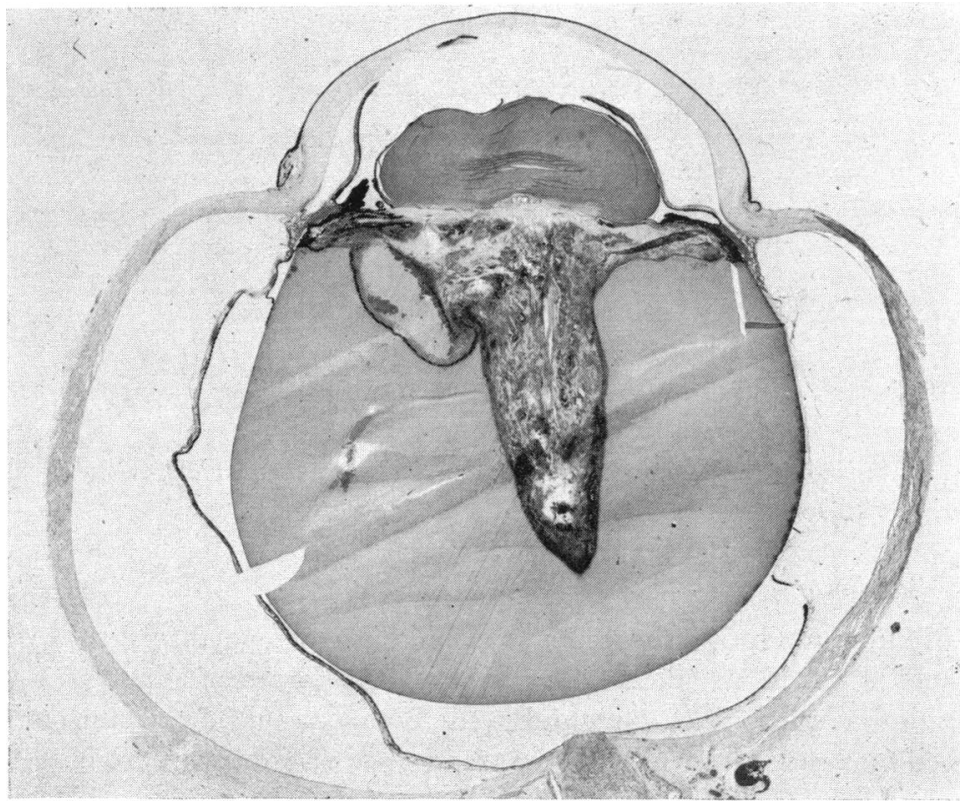

FIG. 24 Case 2. Section of right eye, showing on the left side a preretinal cystic space filled with blood and situated beneath a membrane of proliferated vessels. The degenerate and gliosed retina contains some rosettes. The ciliary processes are drawn towards the lens by fibrovascular tissue. Haematoxylin and eosin. $\quad \times 7$ 
(2) Case 7 (histology already described under FRD) because of the use of antimonycontaining tablets during pregnancy, although we know of no other case of antimonyinduced malformations.

\section{Leucocoria of unknown type}

Some cases in the literature provide no clue as to their cause. Pregnancy, delivery, and family history are unremarkable and the child is otherwise healthy in every way, while the histological changes in the eye are nonspecific. Such cases have been reported by Galloway in (1932), Stefani (I97I), and Warburg (r966), who called them "sporadic". In fact, most $\vec{\circ}$ of our cases, even in the presence of conspicuous data in the history, could be assigned to this group.

Our unilateral Case I I, for example, which has not yet been discussed, was born post- $\frac{\partial}{0}$. maturely and had no significant family history, and the eye showed a total stalk-like retinal $\mathcal{O}_{\infty}$ detachment (Fig. 25) with marked retinal gliosis with true rosettes and vasoproliferative $r$ changes (Fig. 26). There were vitreal strands (Fig. 27) and duplication of the retina but $\overrightarrow{8}$ no haemorrhage. It can be said only that this case represents a congenital retinal detach- $\mathrm{O}$ ment of unknown aetiology.

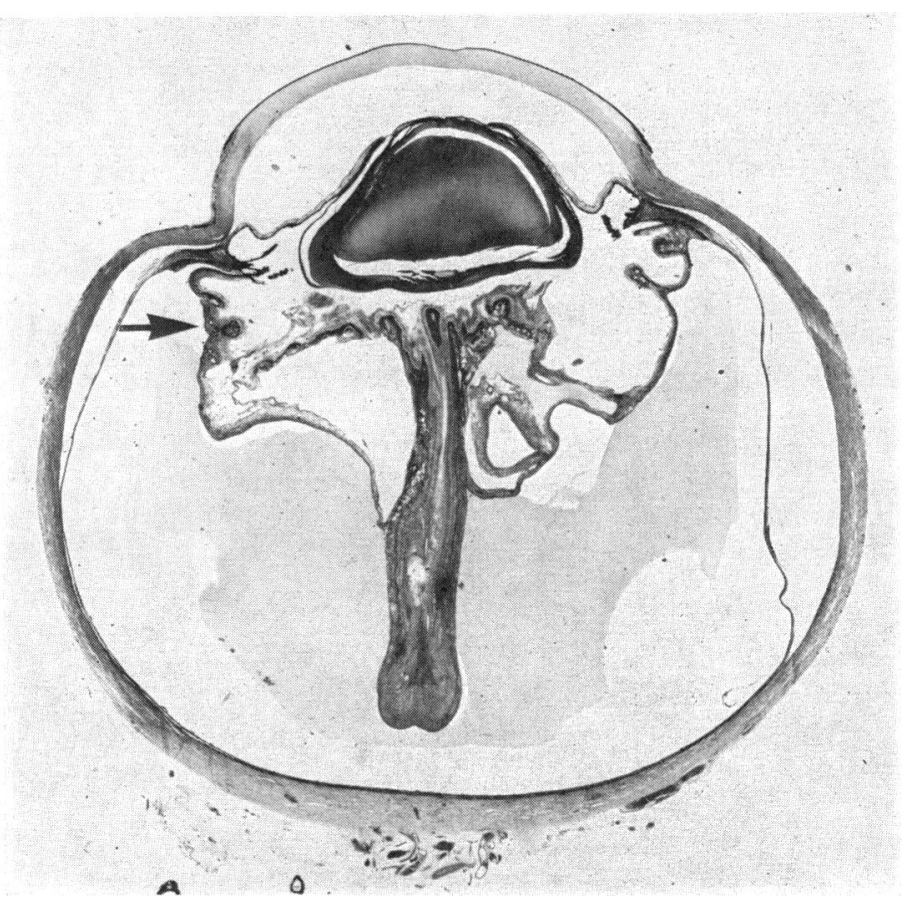

FIG. 25 Case II. Section of left eye, showing stalk-like retinal detachment with vasoproliferative changes and $\stackrel{0}{\frac{0}{C}}$ vitreo-retinal adhesions. Haematoxylin and eosin. $\quad \times 8$

Associated bone disorders

Fraser and Friedmann ( 1967 ) showed a combination of eye disorders with ill-defined $\stackrel{\odot}{\mathbb{D}}$ generalized skeletal affections (their Cases M8 to i8). Forrester's Case 3 (I963), showing several skin angiomata, lipodystrophy, and cystic bone changes, was reported to be similar to that described by Sanders (1952). A widespread bone disorder was presented by Forrester 


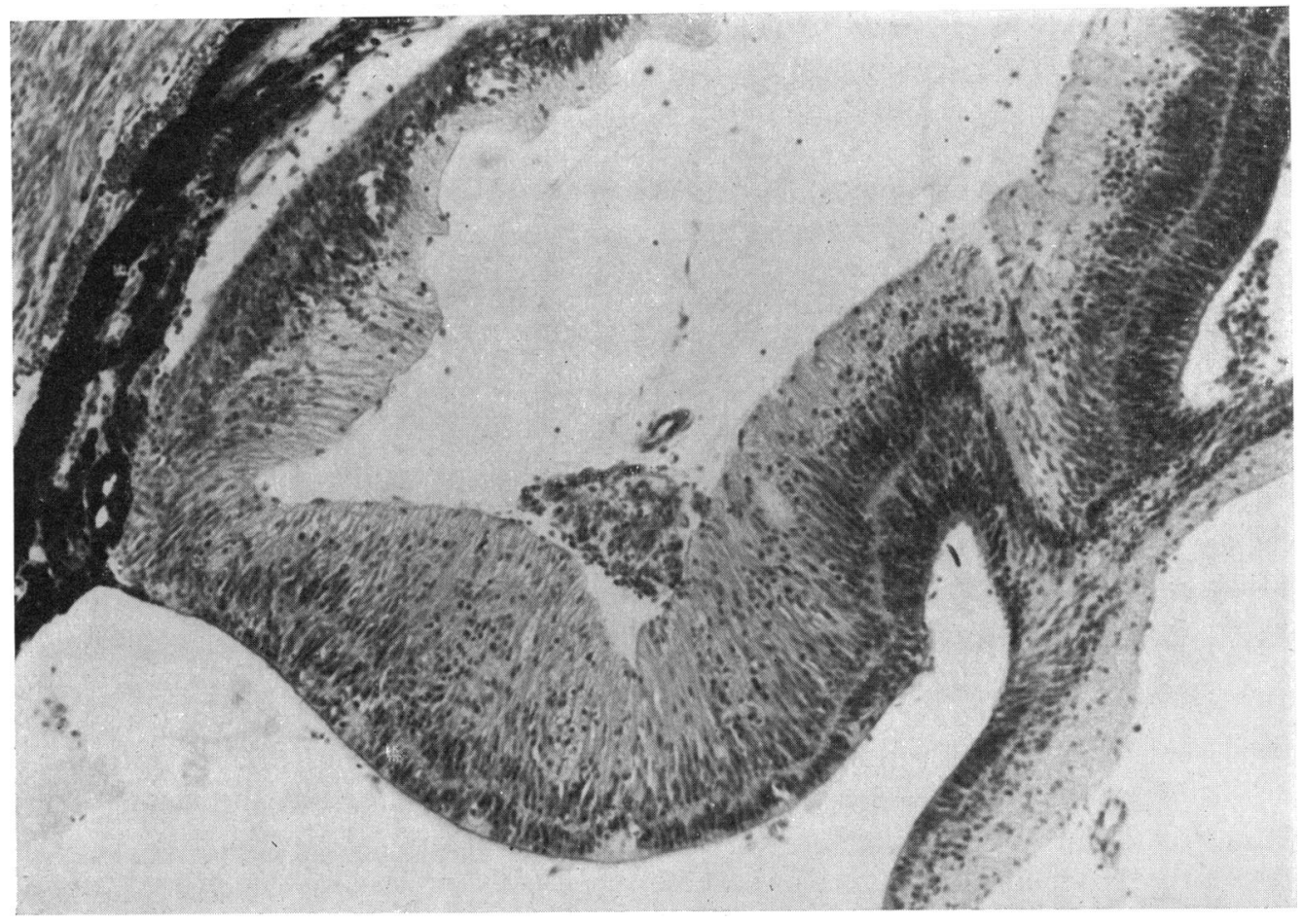

FIG. 26 Case II. Portion of detached retina, showing duplication and preretinal glomerular proliferation of endothelial cells. Haematoxylin and eosin. $\quad X$ I 12

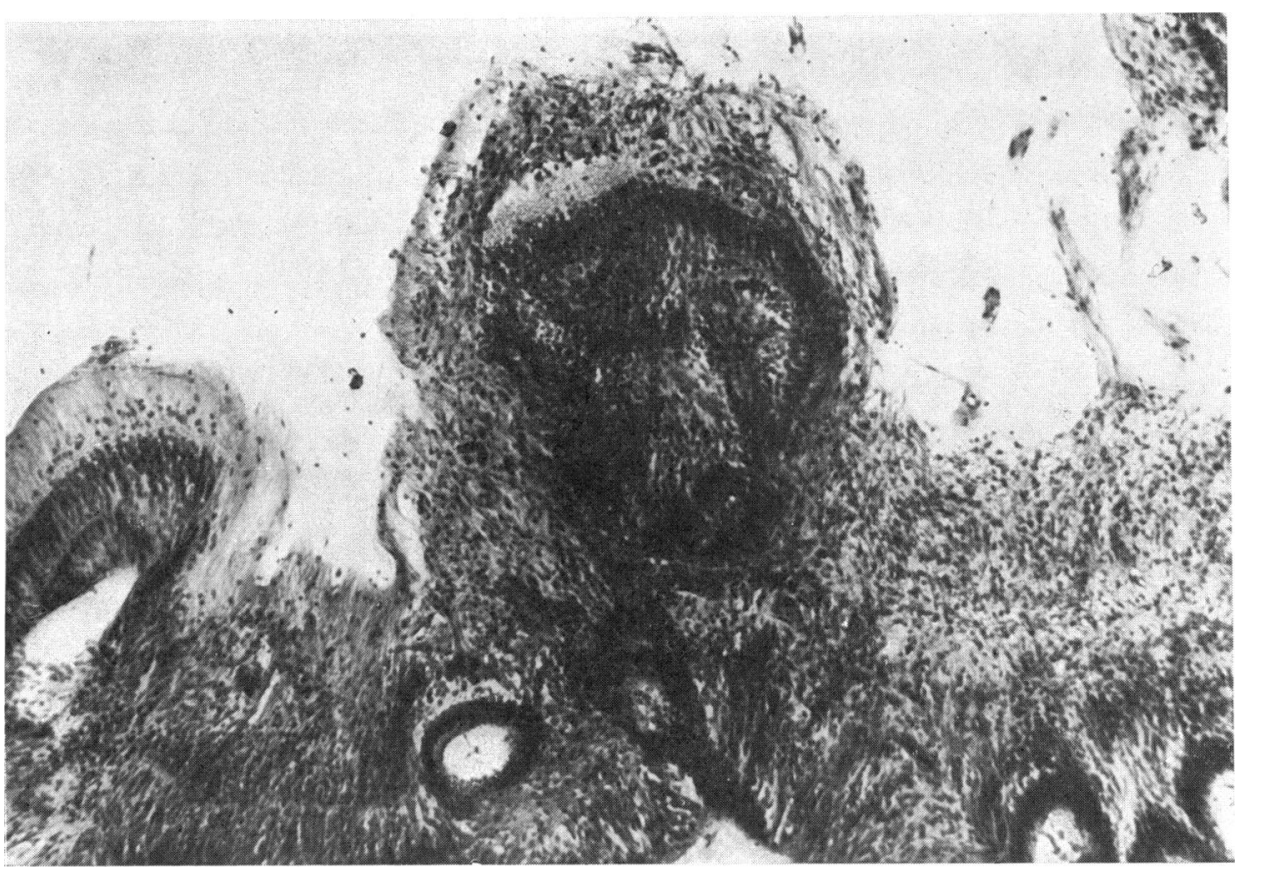

FIG. 27 Case I I. Portion of detached and folded retina with vitreo-retinal adhesions (Arrowed, Fig. 25). Haematoxylin and eosin. $\times$ I00 
(1963) in his Case 6, with dwarfism, high-tone deafness, mental retardation, and cleft palate. This case was again reported by Fraser and Friedmann (1967: Case M 8) and is similar to our Case 5, Forrester's ( I963) Case 4, and Fraser and Friedmann's ( 1967) Case $\mathrm{C}_{2}$, which showed stunted growth, mental retardation, and bilateral leucocoria. In this connection we would refer to the case of Karlsberg, Green, and Patz (1973), which showed besides bilateral "congenital RLF", cleft palate, vestigial cerebellum, and hydrocephalus. The possibility that our Case 9 might be an example of familial cranio-facial disorder has already been discussed.

\section{Summary}

A clinical and histological review is presented of ten bilateral and five unilateral cases of retinal detachment with retinitis proliferans in the eyes of full-term infants who had not been given supplemental oxygen. The cases had been collected over the last 19 years as "non-oxygen induced retinitis proliferans in full-term infants".

We have discussed the diseases and conditions to be considered in the differential diagnosis : these include retrolental fibroplasia, Coats's disease, Norrie's disease, falciform retinal detachment, retinal dysplasia, retinal detachment and intraocular haemorrhage due to birth trauma or physical abuse (battered baby syndrome), congenital retinal detachment due to inflammation during intrauterine life, chromosomal aberrations, and teratogenic agents.

A confident diagnosis was, however, usually impossible. One proved to be a sex-linked inherited disorder (Case 5). Three were classified as falciform retinal detachment (Cases 4 , 7: and 12). Congenital malformation due to exogenous noxae in three (Cases 2, 3, and 7) and spontaneous mutation in one (Case I) were suggested as possible diagnoses. The favoured diagnosis in three was Coats's disease (Cases I 3, I4, and I5). The five remaining cases could not be classified at all, and it seems that they belong to different clinical entities.

It is concluded that vasoproliferation is a nonspecific, secondary reaction occurring not only in retrolental fibroplasia but also in a number of pathological conditions wherein retinal detachment is a common feature. The fundamental cause of the vasoproliferation remains obscure. Although the histopathological appearances in our cases were very similar to RLF (especially in Cases 3, 8, 9, I0, and 12), it is our opinion that this diagnosis should be made only in the presence of prematurity and oxygen therapy.

It is a pleasure to acknowledge the kind co-operation of the many clinicians concerned in the follow-up enquiry. We thank especially Prof. Norman Ashton, F.R.S., for offering us the study of these interesting slides and for his valuable advice and criticism.

We are grateful to Miss E. FitzGerald for her secretarial help with the considerable correspondence and to Mr G. Knight for technical assistance.

\section{References}

ASHTon, N. (196I) Trans. ophthal. Soc. U.K., 81, I 45

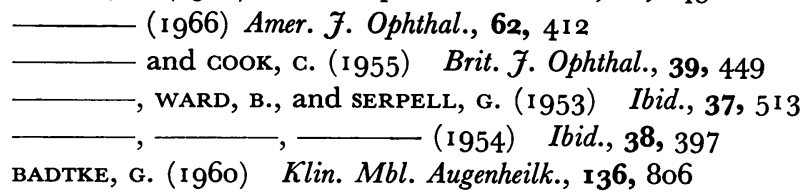

ballantyne, A. J., and michaelson, I. c. (1970) "Textbook of The Fundus of the Eye", 2nd ed.,

p. 259. Livingstone, Edinburgh 
BARDElli, A. M., and Molinelli, G. (1968) Minerva oftal. (Torino), 10, 33

BARSEWISCH, B. VON (1969) Ber. dtsch. ophthal. Ges., 69, 48 I

BLODI, F. C., and HUNTER, w. s. (1969) Docum. Ophthal., 26, 434

BRÜCKNER, H. L. (1968) Arch. Ophthal. (Chicago), 80, 504

Capella, J. A., Kaufman, H. E., Lill, F. J., and cooper, G. (1963) Amer. J. Ophthal., 56, 454

COLE, J. G., and COLE, H. G. (1959) Ibid., 47, 32 I

DEKKING, H. M. (1949) Ophthalmologica (Basel), II 7, I

DIXON, J. M., and PAUl, E. v. (195I) Amer. F. Ophthal., 34, no 5, pt II, p. 182

DUKe, J. R., and woods, A. c. (1963) Brit. F. Ophthal., 47, 41 3

FindLAY, G. H. (1952) Brit. F. Derm., 64, I4I

FISCHBACH, H. (1937) Z. Kinderheilk., 58, 630

FORRESTer, R. M. (1963) Proc. roy. Soc. Med., 56, 994

FRANÇOIS, J., BERGER, R., and SARAUX, H. (I972) "Les abérrations chromosomiques en ophtalmologie." Masson, Paris

FRASER, G. R., and FRIEDmanN, A. I. (1967) "The Causes of Blindness in Childhood. A Study of 776 Children with Severe Visual Handicaps.” Johns Hopkins Press, Baltimore

Galloway, N. P. R. (1932) Trans. ophthal. Soc. U.K., 52, 553

GYLLENSTEN, L. J., and HeLlSTRÖM, B. E. (1955) Brit. F. Ophthal., 39, 409

HEYdENREICH, A. (1959) Klin. Mbl. Augenheilk., 134, 465

hUnter, w. s., and zimmerman, L. E. (1965) Arch. Ophthal. (Chicago), 74, 23

KARLSBERG, R. C., GREEN, W. R., and PATZ, A. (I973) Ibid., 89, I 22

KIFFNEY, G. T., JR. (1964) Ibid., 72, 23 I

lachman, G. s. (1927) Amer. F. Ophthal., 10, 164

mackensen, G. (1953) Klin. Mbl. Augenheilk., 123, 4 I 7

MANN, I. (1935) Brit. 7. Ophthal., 19, 641

maumenee, A. E. (1962) Trans. Amer. ophthal. Soc., 6o, 140

mizuKawa, T. (1955) Acta Soc. Ophthal. jap., 59, 940

MUSHin, A., and MORGAN, G. (I97I) Brit. F. Ophthal., 55, 343

ORTS LlORCA, F., and GENis GALVEZ, J. M. (1960) Arch. Soc. oftal. hisp-.amer., 20, 9 I

PATZ, A. (1955) Trans. Amer. Acad. Ophthal. Otolaryng., 59, 25

PELláthy, B. von (193I) Z. Augenheilk., 73, 249

POULSEN, A. G. (1947) Acta ophthal. (Kbh.), 25, 447

REESE, A. B. (1936) Amer. F. Ophthal., 19, 576

(1949) Arch. Ophthal. (Chicago), 41, 527

and BLodi, F. c. (1951) Amer. F. Ophthal., 34, I

SANDERS, T. E. (I952) Ibid., 35, 6I

scott, J. G., friedmann, A. J., chitters, m., and Pepler, w. J. (I955) Brit. F. Ophthal., 39, 276

STEFANI, F. H. (197I) Münch. ophthal. Ges., 27, I I

Unsworth, A. C. (1949) Trans. Amer. ophthal. Soc., 47, 738

WARBURG, M. (1965) Trans ophthal. Soc. U.K., 85, $39 \mathrm{I}$

- (1966) Acta ophthal. (Kbh.), 44, Suppl. 89

weve, H. (1935) Arch. Augenheilk., 109, 37 I

(1938) Brit. 7. Ophthal., 22, 456

wise, G. N. (1961) Amer. F. Ophthal., 52, 637 